\title{
ARCHITECTURAL STYLE AND QUANTIFICATION OF A SUBMARINE CHANNEL-LEVEE SYSTEM LOCATED IN A STRUCTURALLY COMPLEX AREA: OFFSHORE NILE DELTA
}

\author{
VICKY CATTERALL, ${ }^{*}$ JONATHAN REDFERN, ROB GAWTHORPE, ${ }^{\dagger}$ DORTHE HANSEN ${ }^{\S}$ AND MYRON THOMAS \\ Basin Studies and Petroleum Geoscience, School of Earth, Atmospheric and Environmental Sciences, University of Manchester, Williamson Building, Oxford Road, \\ Manchester, M13 9PL, U.K. \\ e-mail: v_catterall@hotmail.co.uk
}

\begin{abstract}
A Pleistocene channel-levee system located in a structurally complex area of the offshore Nile Delta is studied using a high-resolution three-dimensional (3D) seismic dataset. The seismic facies and stacking patterns are characterized and quantitative analysis of its morphology (e.g., thalweg longitudinal profile, relief, width, and levee thickness) is utilized to understand the controls on channelized-flow processes and resultant architecture. Overall a change downslope from a degradational to aggradational style is observed, which can be related to the concave-up slope profile. In comparison to other channel-levee systems the Noor has a shorter length scale and displays a steepened thalweg slope. This is interpreted to be influenced by structural movements and an associated knickpoint, which controlled a change in flow processes (e.g., velocity, turbulence, and thickness) and the associated location of the canyon to channel-levee transition zone. An unusual feature of downslope levee thickening is observed. Instead of the normal reduction in overbank sedimentation downslope, it is suggested that structural modification causing relative steepening of seabed topography resulted in increased turbidity-current velocity, fluid volume discharge, and associated sediment load, which overcame the normal downslope loss of sediment due to overbank sedimentation. This study shows that architectural style is strongly linked to slope topography, and that structural movements can influence the slope profile and flow process, resulting in modification of the morphology and dimensions of channel-levee systems.
\end{abstract}

\section{INTRODUCTION}

Direct observations of the sedimentary processes that control the evolution of submarine channels are rare. Documenting the facies, depositional elements, and stratigraphic architecture of channels provides valuable information needed to improve understanding of their processes and to unravel their morphological control and development. The temporal evolution of channel architecture is often inferred to be linked to changes of relative sea level. Falling sea level drives erosional processes that lead to the initiation of an erosional container, and depositional processes fill the erosional container during sea-level rise (e.g., Deptuck et al. 2003; Posamentier and Kolla 2003; Samuel et al. 2003; Beaubouef 2004; Mayall et al. 2006; Gee et al. 2007; Cross et al. 2009). Studies of the downslope change of submarine channel architecture, however, highlight the importance of the longitudinal slope to basin-floor profile (McHargue and Webb 1986; Gardner and Borer 2000; Babonneau et al. 2002; Eschard et al. 2003) and the influence of the equilibrium profile on development of architectural style (Pirmez et al. 2000; Kneller 2003; Ferry et al. 2005).

Using 3D seismic data from the central Nile Delta slope, this study investigates the architectural variation of the Noor channel-levee system and quantifies channel-levee system morphology (e.g., thalweg longitudi-

* Present address: ExxonMobil International, ExxonMobil House, MP45, Ermyn Way, Leatherhead, Surrey KT22 8UX, U.K.

$\dagger$ Present address: Department of Earth Sciences, University of Bergen, Allegaten 41, N-5007, Bergen, Norway

$\S$ Present address: Statoil (UK) Ltd, Statoil House, 11a Regent Street, London, SW1Y 4ST, U.K. nal profile, width, depth, levee thickness) to assess the influence of local slope tectonics and potential external factors (e.g., sea level, sediment supply) on the evolution of architectural style. Although quantification of submarine channel-levee systems is well documented for modern systems (e.g., Pirmez and Flood 1995; von Rad and Tahir 1997; Babonneau et al. 2002; Deptuck et al. 2007; Wood and Mize-Spanksy 2009) there are fewer subsurface examples (e.g., McHargue and Webb 1986; Deptuck et al. 2007; Gee et al. 2007). Analysis of subsurface channel systems is challenging due to time-to-depth conversion of seismic data and possible compaction effects modifying the observed channel-levee morphology (Deptuck et al. 2007). However, 3D seismic data that image large subsurface volumes offer a unique opportunity to evaluate channel architecture and relationships to slope topography, and to describe and quantify systems over distances far exceeding outcrop data (Normark et al. 1993).

By examining and quantifying the Noor channel-levee system and placing it in context on the Nile Delta slope, it is possible to gain a clearer understanding of the controls on channel location, architecture, and evolution, which allows depositional models to be developed that can be applied to slope channels on other continental margins.

\section{GEOLOGICAL SETTING}

The Nile Delta builds into the Eastern Mediterranean Sea on the North African continental margin (Fig. 1A). The central province of the Nile Delta slope (Mascle et al. 2001) contains the Pleistocene age Noor channel-levee system. The central province contains two major structures; the Rosetta Fault and the Nile Delta Offshore Anticline (NDOA) (Fig. 1B, Said 1981; Abdel Aal et al. 2000, 2001; Samuel et al. 2003). The 


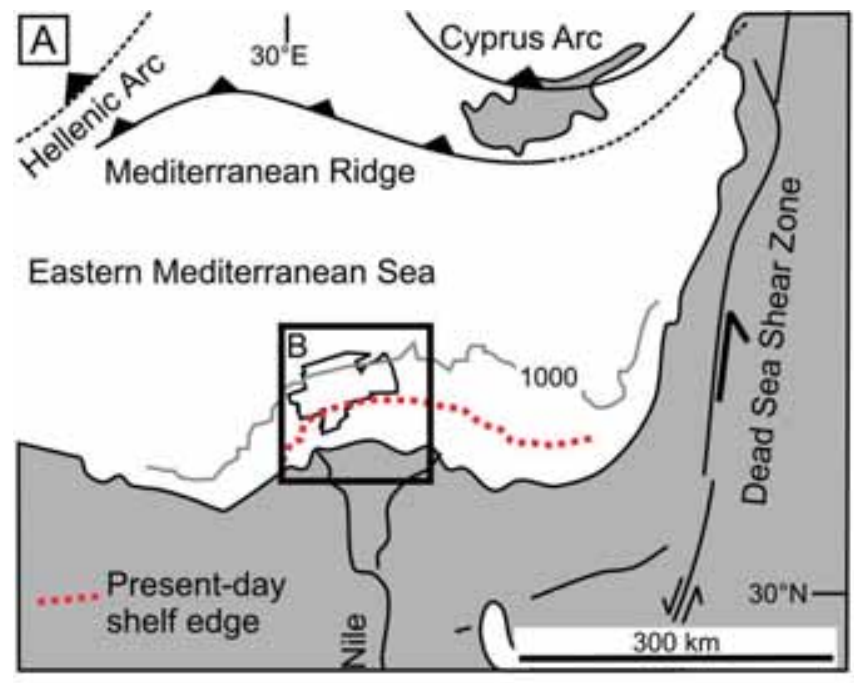

B

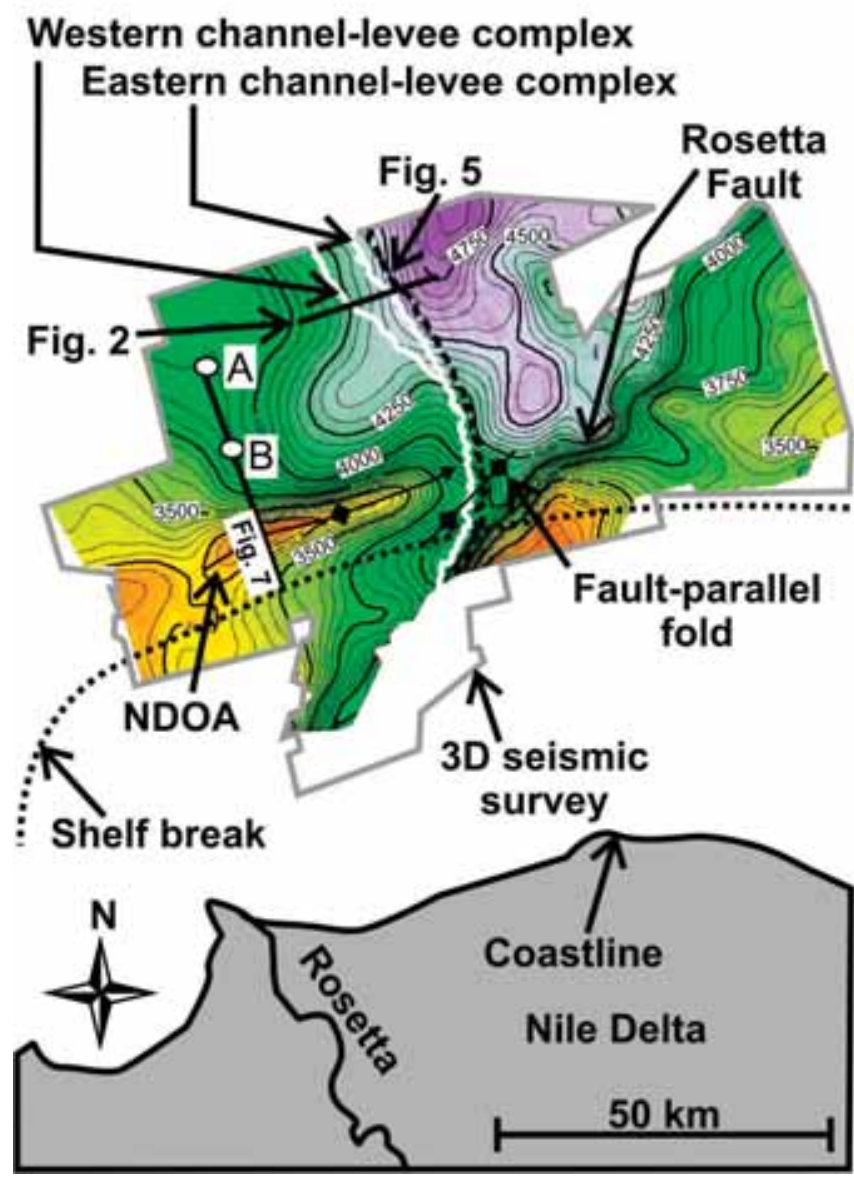

FIG. 1.- Overview of the study area and dataset. A) The location of the study area in the Eastern Mediterranean Sea with $1000 \mathrm{~m}$ bathymetric contour and the location of the 3D seismic survey in the central province of the Nile Delta. B) The time-structure (two-way travel time, ms) map of the top Messinian surface shows the location of the NE-SW-trending Rosetta Fault and the Nile Delta Offshore Anticline (NDOA). The location of the fault-parallel fold as observed in the Pleistocene succession is also shown. The solid lines located in the central part of the seismic survey show the thalweg of the Noor channel-levee system. The dashed line represents the eastern flank of the
Rosetta Fault strikes NE-SW and can be traced for approximately $100 \mathrm{~km}$ in the study area (Fig. 1B). The ENE-WSW-trending NDOA is located to the northwest of the Rosetta Fault in the western part of the study area (Fig. 1B). The asymmetric NDOA has a steeper northern limb and an axis that plunges to the ENE. In proximity to the Noor channellevee system, a fault-parallel fold developed $\sim 10 \mathrm{~km}$ north of the central part of the Rosetta Fault with an axis trending nearly parallel to the Rosetta Fault (Fig. 1B).

\section{METHODOLOGY}

Dataset

The 3D seismic survey covers an area of approximately $5700 \mathrm{~km}^{2}$ and is located 25-50 km offshore the present-day coastline of Egypt (Fig. 1). The dataset is nearly zero-phase migrated, displayed as reversed polarity (SEG standard, Sheriff and Geldart 1995) and has a bin spacing of $25 \times 25 \mathrm{~m}$. The seismic interval containing the Pleistocene Noor channel-levee system has a frequency range of 40-60 Hz and an interval velocity of $1600 \mathrm{~m} / \mathrm{s}$. The resulting tuning thickness (vertical resolution) $(\lambda / 4)$ is $5-10 \mathrm{~m}$.

\section{Stratigraphic Hierarchy and Architectural Style}

The Noor is defined in this study as a channel-levee system on the basis of its morphology and stratigraphic hierarchy. It comprises two channellevee complexes made up of several channels and levees fed by the same canyon (Fig. 2). A similar convention was used to describe the Amazon fan by Damuth et al. (1983).

The Noor channel-levee system has been subdivided into different depositional environments to allow description of its morphology and architectural style. Four depositional environments are defined: (1) channel axis, (2) overbank, (3) abandonment, and (4) prodelta (Fig. 3). Each depositional environment is characterized based on: (a) description of seismic facies; (b) interpretation of the sedimentary processes controlling facies deposition and definition of the depositional element; and (c) description of stacking patterns, both of the depositional elements and in a particular depositional environment.

\section{Mapping}

A basal erosion surface and a top surface were mapped along the length of the Noor channel-levee system to facilitate imaging of its fill (Fig. 3). Over most of the Noor the mapped basal erosion surface truncates an underlying package of subparallel, continuous reflections. Mapping the basal erosion surface was challenging in the distal sections of the dataset because the underlying continuous and subparallel reflections are replaced with a chaotic, low-amplitude facies. In this area the basal erosion surface was mapped based on the boundary between the high-amplitude reflections of the channel-axis deposits and the underlying chaotic, low-amplitude facies.

The top surface was mapped as the first continuous reflection that could be traced above the Noor channel-levee system over most of its length (Fig. 4). In the distal parts of the Noor, the surface is truncated by a mass-transport complex, and the base of the mass-transport complex was mapped as the top surface (Fig. 4C).

Initially, the basal erosion surface was mapped along seismic strike lines (inlines) and maximum seismic amplitude extracted from between the basal erosion and top surface. This amplitude extraction was used to generate 35 cross sections oriented perpendicular to the channel-levee

$\leftarrow$

basal erosion surface, along which Figure 5 is located. The location of the present-day shelf break is demarcated by the dotted line. This figure is in color in the on-line version. 


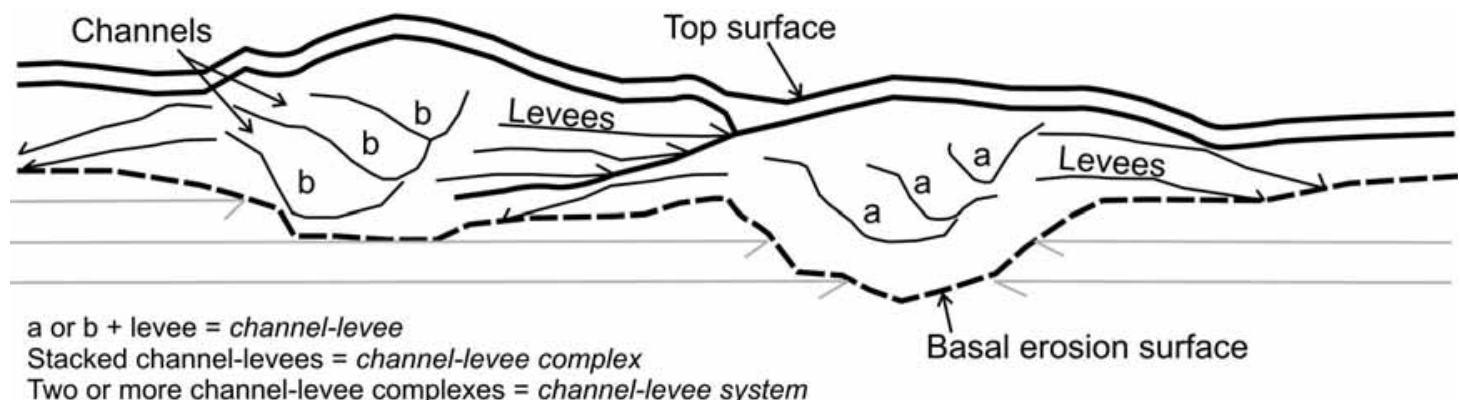

FIG. 2.-The stratigraphic hierarchy of the Noor channel-levee system. Schematic diagram is based on the distal mapped parts of the Noor showing the nomenclature used to define it (approximate section location is shown in Fig. 1B).

The average depth of the shallowest point on the flank is used for width and relief measurements in the proximal upper reach. In the distal upper reach both the shallowest point on the flank and inflection points are used

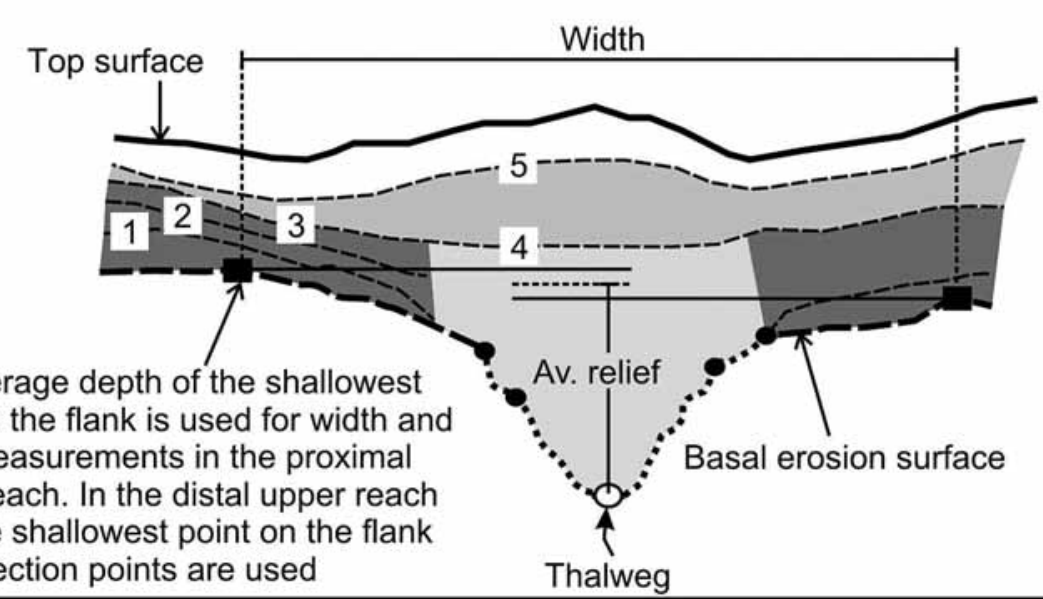

B

\section{Simple basal erosion surface (e.g., Noor channel-levee system, distal middle reach)}

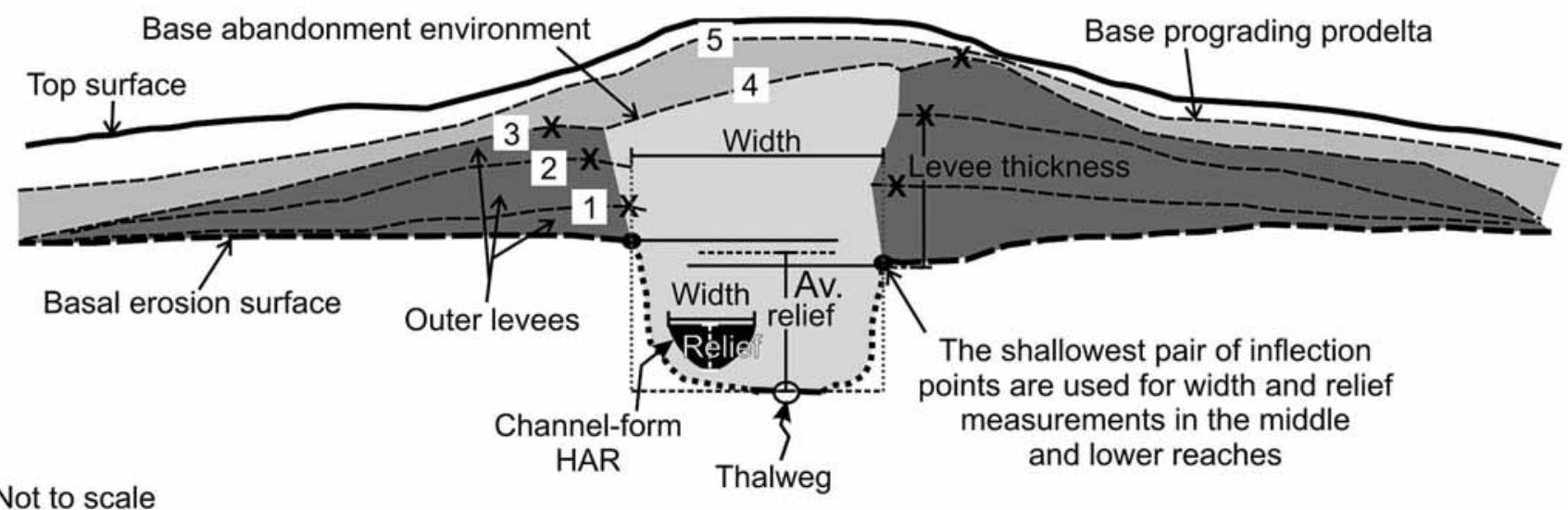

FIG. 3.- Overview of the depositional environments, mapped surfaces, and methodology used for quantification. A) Schematic diagram based on the upper reach of the Noor channel-levee system, where the basal erosion surface has a complex morphology with multiple inflection points. Relief and width measurements of the basal erosion surface are shown. B) Schematic diagram based on the distal middle reach, where the basal erosion is simple with only one pair of inflection points. Measurements of outer-levee crests and the width and relief of the channel-form high-amplitude reflections (CF HARs) are shown. 


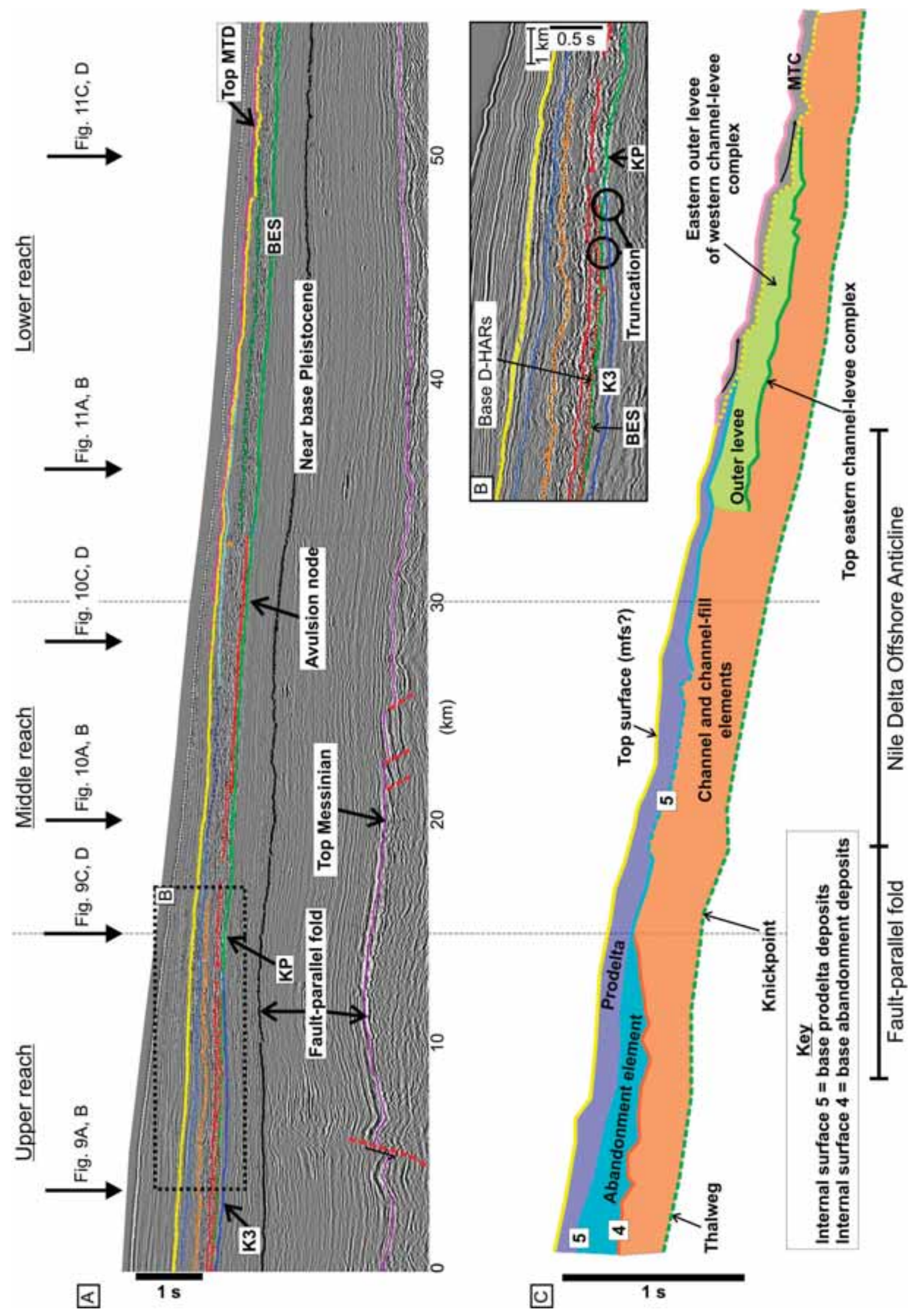

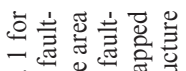

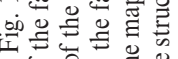

象

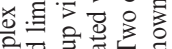

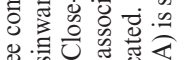

응

舟

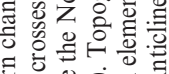

密

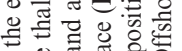

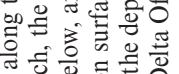

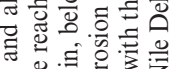

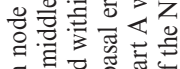

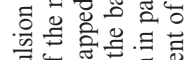

证

월

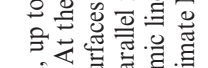

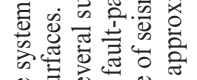

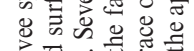

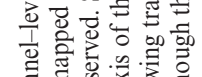

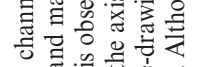

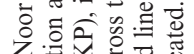

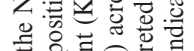

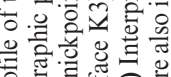

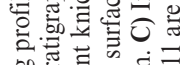

कo

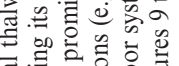

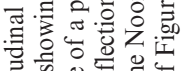

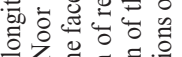

을

吅

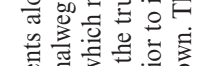

氙焉

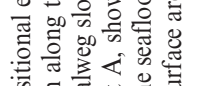

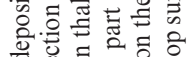

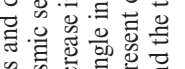

语.

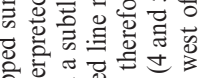

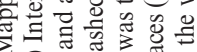

人훙훙

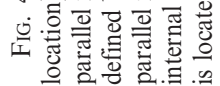



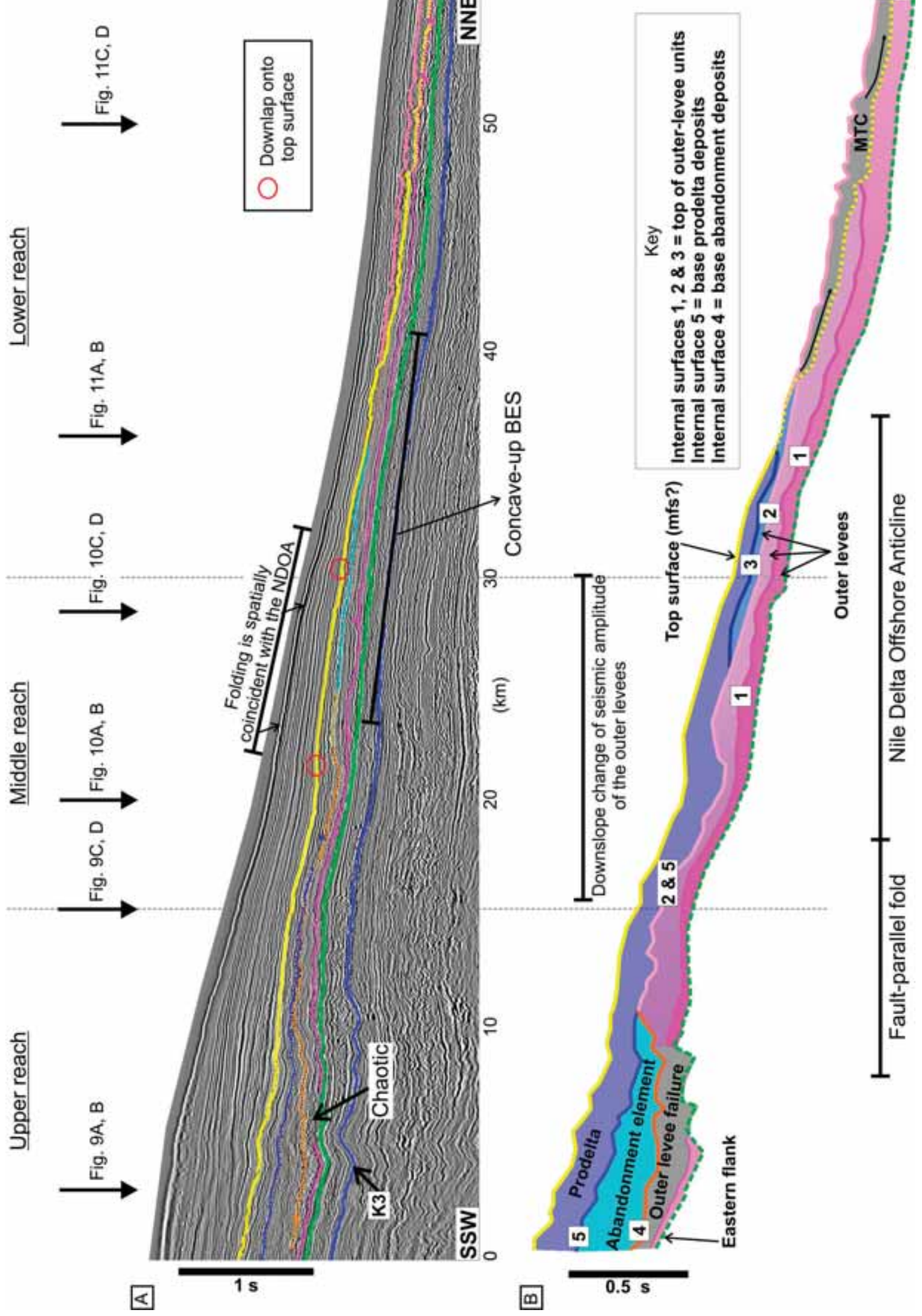

号 


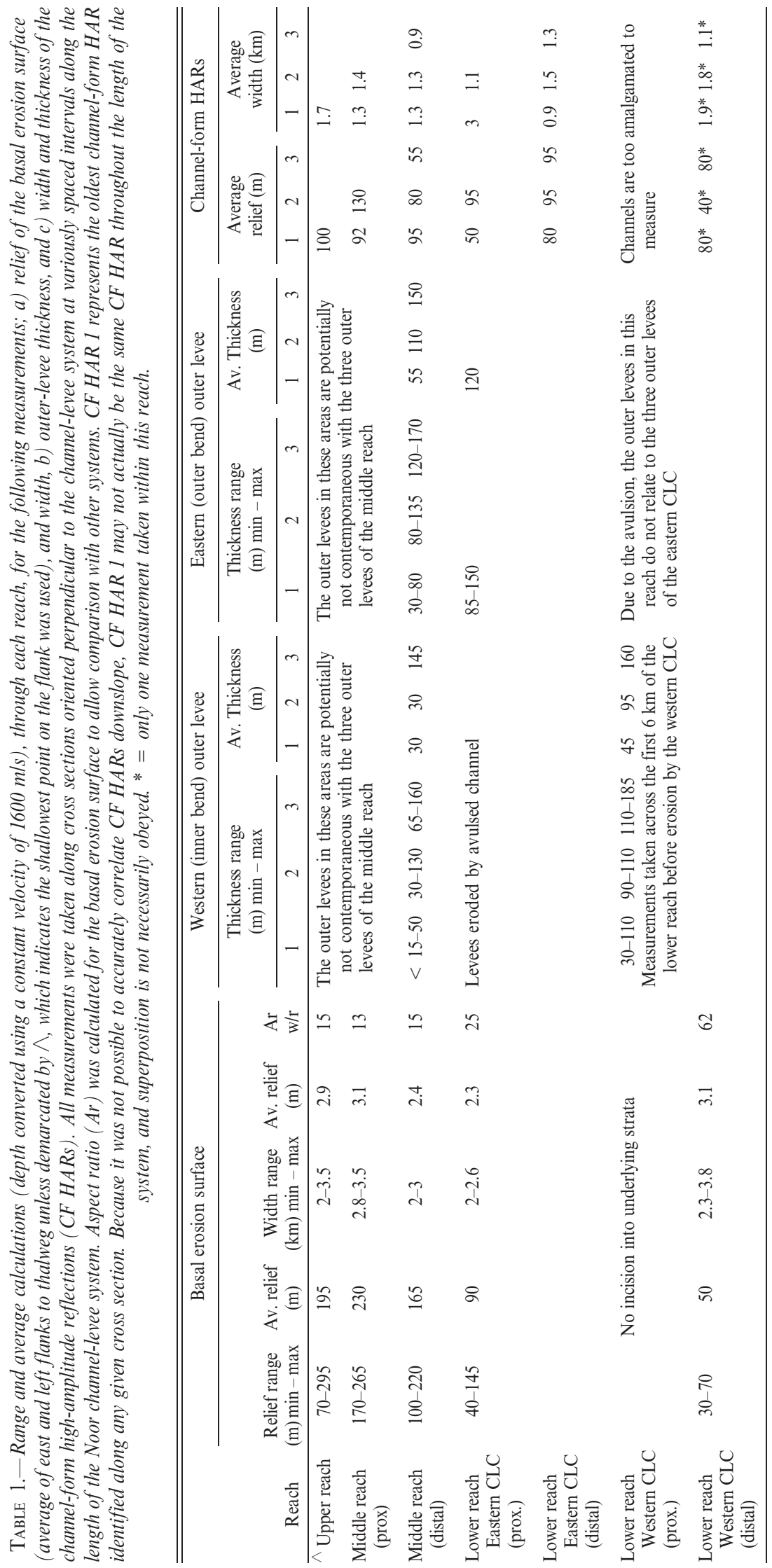


system. The pick of the basal erosion surface was then refined using the cross sections. The second and more detailed phase of mapping was carried out using cross sections spaced 25 to $125 \mathrm{~m}$ apart, located between the initial set of 35 cross sections.

The deepest part of the basal erosion surface is defined as the Noor thalweg (Fig. 3), and the near vertical margins are termed sidewalls (Fig. 3). Subhorizontal sections of the basal erosion surface on either side of the sidewalls are referred to as flanks (Fig. 3). Cross-sectional changes in geometry of the basal erosion surface define inflection points (Fig. 3), and where several pairs of inflection points are identified, the shallowest pair is used to mark the contact between sidewalls and flanks (Fig. 3).

Five surfaces in the Noor channel-levee system (termed internal surfaces) that mark the top or base of a distinctive seismic facies were also mapped and are numbered 1 to 5 (Figs. 3, 4, 5). It has not been possible to map internal surfaces in the channel axis deposits due to their discontinuous and crosscutting character. To document the plan-form geometry of these channel-axis deposits, isoproportional slicing between the basal erosion surface and top surface was carried out and maximum seismic amplitude was extracted between the isoproportional slices.

\section{Quantification}

Detailed measurements in two-way travel time (TWTT) of the thalweg, inflection points, flanks of the basal erosion surface (east and west), and outer levee crests (Fig. 3) were taken every $125 \mathrm{~m}$ along the length of the Noor, and their respective longitudinal profiles are presented in Figure 6. From these measured parameters, the relief of the basal erosion surface and the thickness of the outer levees were determined. For specific reaches, the range and average of these parameters are presented in Table 1. Depth conversion was carried out using interval velocities extracted from a nearby exploration well that intersects the axis of a comparable channel located at a depth similar to that of the Noor. Sediment velocities range from 1600 to $1680 \mathrm{~m} / \mathrm{s}$, and a constant sediment velocity of $1600 \mathrm{~m} / \mathrm{s}$ was applied to the interval between the basal erosion surface and top surface. Measurements presented in Table 1 are therefore minimum values.

The width of the basal erosion surface and the width and relief of seismic facies characterized by channel-form high-amplitude reflections (CF HARs) located in the channel-axis environment were measured along 35 cross sections oriented perpendicular to the channel-levee system (Table 1)

To better represent the morphology of the basal erosion surface in the proximal parts of the Noor, the shallowest point on the flank of the basal erosion surface was also measured, as well as the shallowest pair of inflection points (Fig. 3). In all other reaches, only the shallowest pair of inflection points were measured (Fig. 3).

A layer-cake depth conversion was carried out to assess if variable overburden and velocity has modified the morphology of the longitudinal profiles in TWTT. Each layer was assigned a constant interval velocity or a velocity function derived from nearby well data. A constant interval velocity of $1470 \mathrm{~m} / \mathrm{s}$ and $1600 \mathrm{~m} / \mathrm{s}$ was used for seawater and the channellevee system (basal erosion surface to top surface) respectively. For the overburden (top surface to seabed) a function that describes the velocity change with depth ( $V_{o}$ and $k$; Slotnick 1936; Al-Chalabi et al. 1997a, 1997b) was used. No major changes to the shape or morphology of longitudinal profiles were observed after depth conversion.

To better represent the morphology of the Noor the depth-converted aspect ratio (width:relief) of the basal erosion surface and the thalweg slope $(\mathrm{m} / \mathrm{km})$ were determined for specific settings along the length of the Noor and compared with similar settings along several analogous channel-levee systems (e.g., Indus, Zaire, and Amazon). As a result of burial and resultant flattening of the thalweg longitudinal profile, the measurements of the thalweg slope $(\mathrm{m} / \mathrm{km})$ of the Noor are minimum values.

\section{Decompaction}

To assess the impact of compaction on levee thickness, a decompaction workflow was carried out using 2D Move ${ }^{\mathrm{TM}}$ software. A seismic dip section located west of the Noor was used (Fig. 1B). Depth conversion of several mapped reflections was carried out first (Fig. 7A) and then decompaction (Fig. 7B). The overburden above the interval containing the Noor system was subdivided into three units, and each unit was assigned a constant-interval velocity (Table 2) (Fig. 7). Several different constant interval velocities were used for each interval rather than one value for the entire overburden as was used to depth convert the longitudinal profiles (Table 2). The velocity data used for depth conversion were provided by BG Group based on well control. Data on porosity and depth coefficients are standard values. The change of interval thickness after decompaction was calculated for two positions (A and B; Fig. 7) located across the northern limb of the NDOA axis in order to assess the impact of compaction on levee thickness.

\section{GEOMORPHOLOGY OF THE NOOR CHANNEL-LEVEE SYSTEM}

From observation of systematic changes in the trend of the basal erosion surface and character of the thalweg longitudinal profile, the Noor channel-levee system was subdivided into three segments along its length, termed upper, middle, and lower reaches. The upper reach extends $15 \mathrm{~km}$ down the thalweg from the updip mapped extent of the system (Fig. 6A). The middle reach is located between 15 and $33 \mathrm{~km}$, and the lower reach extends from $33 \mathrm{~km}$ to the northern edge of the dataset (Fig. 6A).

\section{Basal Erosion Surface}

Through the upper and middle reaches the basal erosion surface is characterized by one curvilinear erosional trough (Fig. 8A). In the upper reach the system trends NNE, near parallel to the Rosetta Fault, until the start of the middle reach, when the trend changes to north (downslope directions) (Fig. 8). Through the middle reach, the channel system is deflected around the east-plunging nose of the Nile Delta Offshore Anticline (NDOA), as the trend of the basal erosion surface changes from $\mathrm{N}$ to NNW (Fig. 8). In the lower reach, two channel-levee complexes are observed: the eastern and western (Fig. 8). Each complex has its own mapped basal erosion surface, and the two surfaces merge upslope at the avulsion node that defines the boundary between the middle and lower reaches (Fig. 8). The older, eastern channel-levee complex was abandoned when the younger western channel-levee complex became active. The western complex progressively diverges away from the abandoned eastern complex in a downslope direction, following a relatively consistent NNW trend (Fig. 8).

The maximum thickness ( $\sim 550 \mathrm{~ms}$ TWTT or $450 \mathrm{~m})$ of the channellevee system is located in the upper reach, towards to the Rosetta Fault (Fig. 8C), decreasing to $<120 \mathrm{~m}(150 \mathrm{~ms}$ TWTT) in the lower reach (Fig. 8C). The minimum thickness of the channel-axis deposits is coincident with the maximum point of thalweg convexity, observed approximately $25 \mathrm{~km}$ along the thalweg, in the middle reach (Y in Figs. 6A, 8C).

Upper Reach.-The relief and cross-sectional geometry of the basal erosion surface change rapidly over the first $15 \mathrm{~km}$. Through the initial $6 \mathrm{~km}$, relief and width of the basal erosion surface, as measured using the shallowest pair of inflection points, is $\sim 150 \mathrm{~m}$ and $\sim 3.5 \mathrm{~km}$ respectively (Figs. 6A, 9A, B). Using the shallowest points on the flanks these measurements increase to $\sim 300 \mathrm{~m}$ and $10 \mathrm{~km}$ (Figs. 6A, 9A, B). Over this segment, the time-dip map of the basal erosion surface shows that the boundary between sidewalls and flanks is weakly defined (Fig. 8D). Downslope, between 6 and $15 \mathrm{~km}$, the boundary becomes a prominent feature and the plan-form morphology of the sidewalls is arcuate (Fig. 8D). In this distal segment of the upper reach, relief and width of 
A

Distance downslope $(\mathrm{km})$

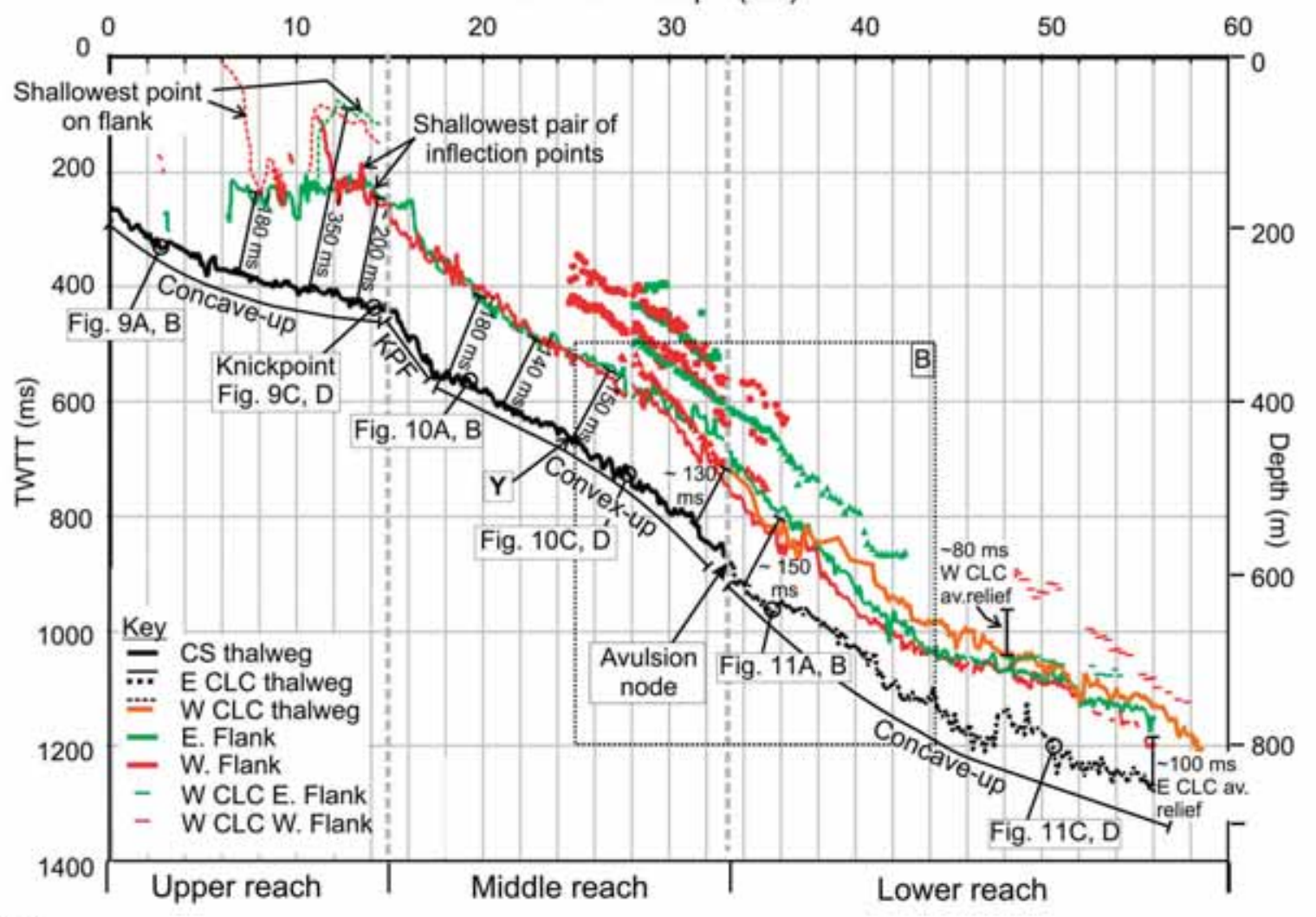

B

Distance downslope $(\mathrm{km})$

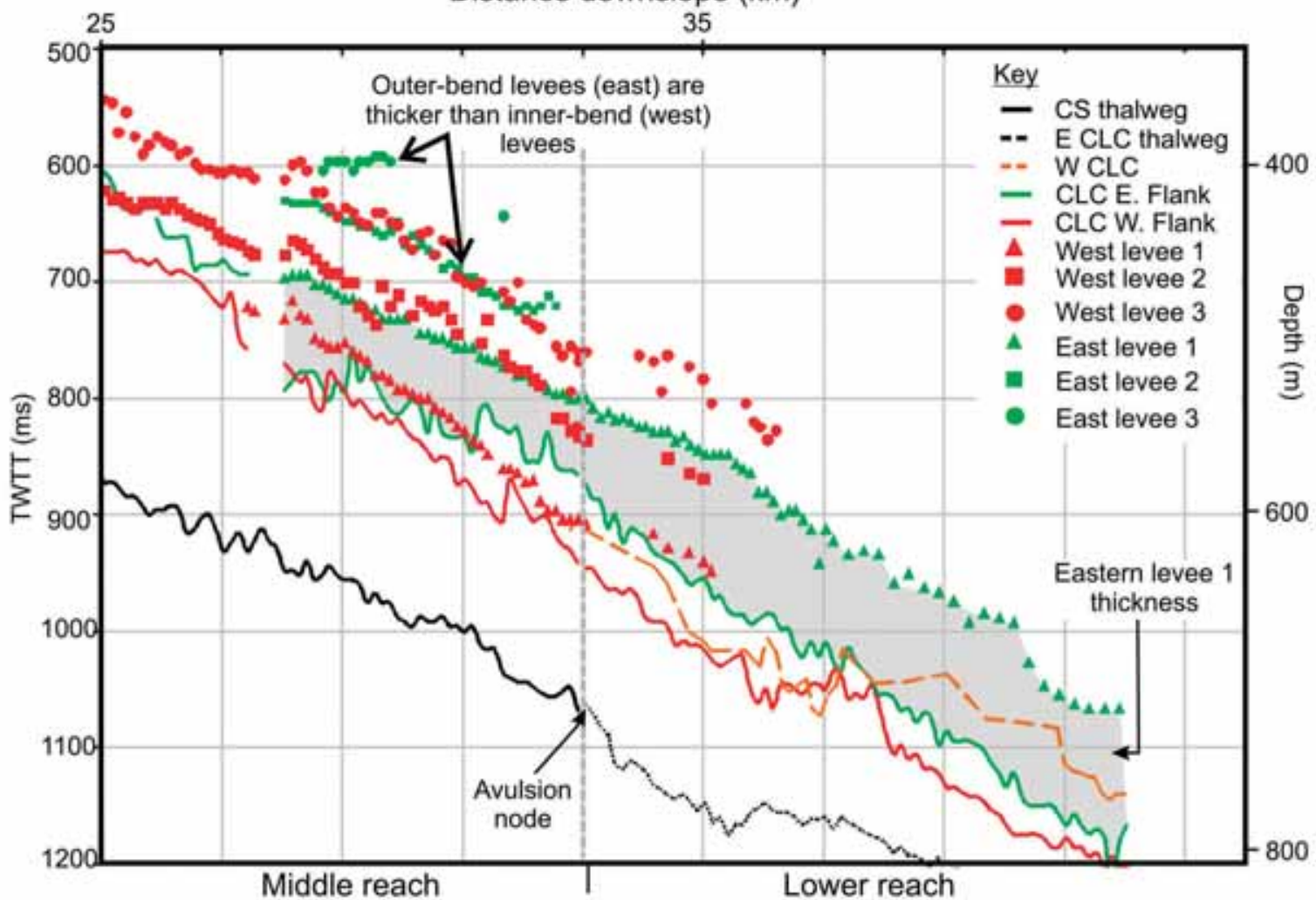



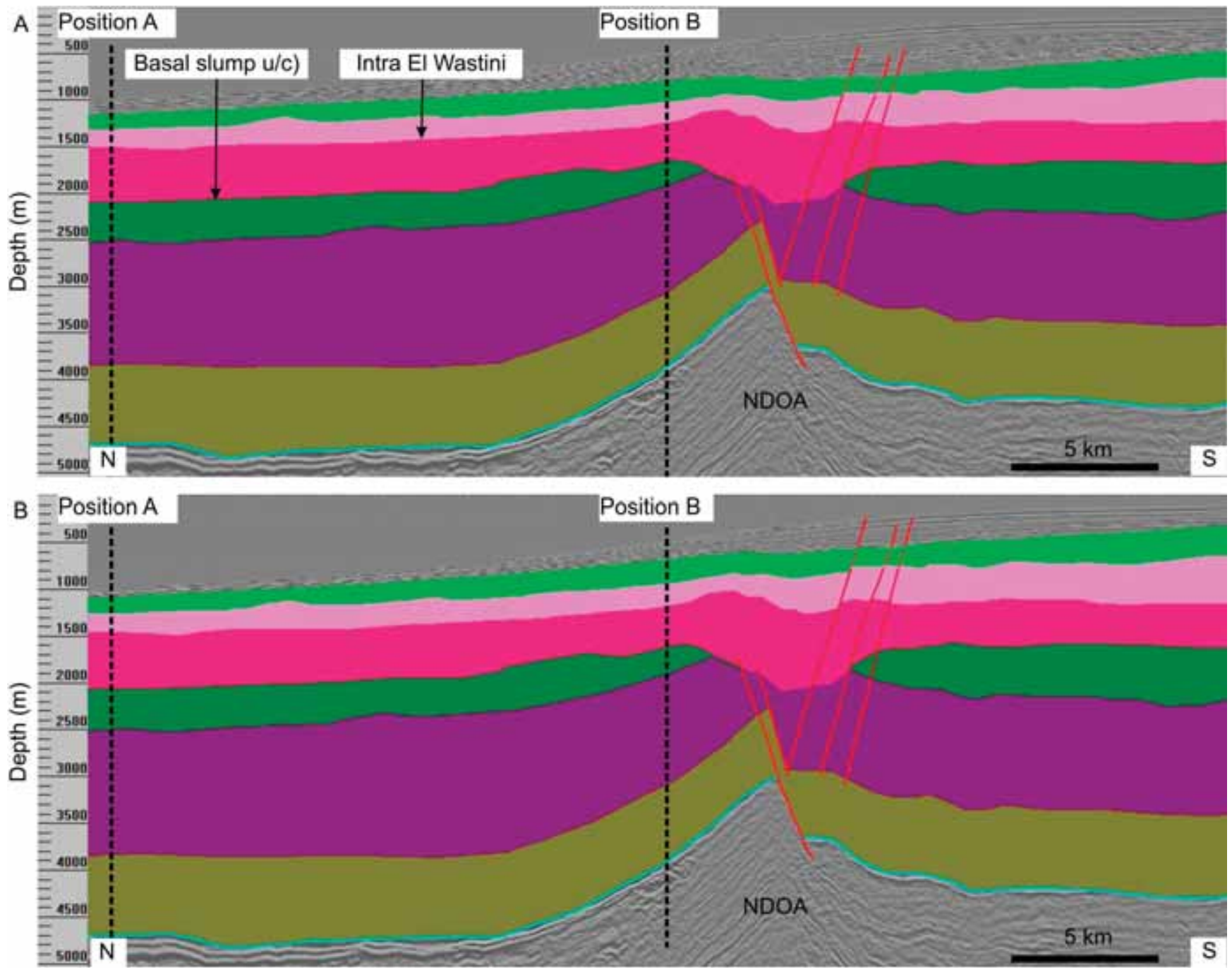

Fig. 7. - Seismic section (see Fig. 1B for section location) showing the mapped surfaces and intervals used for depth conversion and decompaction.

the basal erosion surface is $150-200 \mathrm{~m}$ and $4 \mathrm{~km}$ respectively (Figs. 6A, 9C, D). Measured from the shallowest point on the flanks, relief is $280 \mathrm{~m}$ (maximum) and width $10 \mathrm{~km}$ (Figs. 6A, 9C, D).

Part of the confinement of the channel-axis deposits in the proximal upper reach is related to the concave-up flanks, which mirror the synform geometry of underlying reflections (Fig. 9A, B). Through the distal part of the upper reach, confinement of the channel-axis deposits by the basal erosion surface is related to an increase of relief and sidewall steepening (Fig. 9C, D). Throughout the upper reach the thalweg has a concave-up longitudinal profile (Fig. 6A).

The point at which an increase in relief of the basal erosion surface and the arcuate plan-form morphology of the sidewalls is observed $(6 \mathrm{~km}$ downslope) is immediately upslope of a prominent break in thalweg slope (Fig. 6A). This break in slope, or knickpoint, marks the boundary

Fig. 6.-Results of quantification of the Noor channel-levee system. A) Vertically exaggerated plot along the full mapped length of the Noor system. The thalweg longitudinal profile is described based on its concave-up or convex-up shape. A break of thalweg slope, or knickpoint, at $15 \mathrm{~km}$ marks the boundary between the upper and middle reaches which is coincident with the axis of the fault-parallel fold. An increase of thalweg TWTT/depth located between 15 and $18 \mathrm{~km}$ marks the face of the knickpoint (KPF). The middle reach shows a convex-up thalweg-long profile with the minimum point of convexity marked by Y, which coincides with thinning of the Noor channel-levee system observed in Figure 8C. The avulsion node, at approximately $33 \mathrm{~km}$ downslope, separates the middle and lower reaches. Locations of seismic sections shown in Figures 9 to 11 are shown. Note the downslope decline of relief of the basal erosion surface (area between thalweg and flanks) and increase of relief of the basal erosion surface in the distal upper reach, upslope of the knickpoint. Symbols represent outer-levee crests 1 to 3 see part B for key. B) Expanded section between 25 and $44 \mathrm{~km}$ to show the measurements of the outer-levee crests. The eastern levees (solid shapes) are always shallower, and the levees are therefore thicker than the western levees. The eastern levee 1 thickens downslope. $\mathrm{CS}=$ channel system, $\mathrm{CLC}=$ channel-levee complex, $\mathrm{E}=$ eastern, and $\mathrm{W}=$ western. This figure is in color in the online version. 
TABLE 2.- Input parameters and the results of depth conversion and decompaction carried out along a dip section (see Fig. 1B for section location).

\begin{tabular}{|c|c|c|c|c|c|}
\hline \multicolumn{6}{|l|}{ Position A } \\
\hline Unit & $\begin{array}{c}\text { Depth } \\
\text { Coefficient }\end{array}$ & Porosity & $\begin{array}{l}\text { Compacted } \\
\text { Thickness (m) }\end{array}$ & $\begin{array}{l}\text { Decompacted } \\
\text { Thickness (m) }\end{array}$ & $\begin{array}{c}\text { Thickness } \\
\text { difference }(\mathrm{m})\end{array}$ \\
\hline Seabed - I.B.1 & Stripped off & Stripped off & 146.21 & Stripped off & Stripped off \\
\hline I.B.1. - I.B.2. & 0.51 & 0.51 & 148.47 & 158.39 & 9.92 \\
\hline I.B.2 - I.E.W. & 0.51 & 0.51 & 189.34 & 199.27 & 9.93 \\
\hline I.E.W. - B.S. & 0.51 & 0.51 & 587.48 & 607.09 & 19.61 \\
\hline B.S. - Top K.E.S. & 0.51 & 0.51 & 436.34 & 444.95 & 8.61 \\
\hline Top K.E.S. - SS20 & 0.51 & 0.51 & 1319.17 & 1332.5 & 13.33 \\
\hline SS20- Top Mess & 0.39 & 0.56 & 842.94 & 848.15 & 5.21 \\
\hline \multicolumn{6}{|l|}{ Position B } \\
\hline & Depth & & Compacted & Decompacted & Thickness \\
\hline Unit & Coefficient & Porosity & Thickness (m) & Thickness (m) & difference (m) \\
\hline Seabed - I.B.1 & Stripped off & Stripped off & 290.84 & Stripped off & Stripped off \\
\hline I.B.1. - I.B.2. & 0.51 & 0.51 & 220.1 & 246.85 & 26.75 \\
\hline I.B.2 - I.E.W. & 0.51 & 0.51 & 209.42 & 228.25 & 18.83 \\
\hline B.S. - Top K.E.S. & 0.51 & 0.51 & 233.48 & 243.76 & 10.28 \\
\hline Top K.E.S. - SS20 & 0.51 & 0.51 & 1118.1 & 1146.74 & 28.64 \\
\hline SS20- Top Mess & 0.39 & 0.56 & 858.43 & 871.8 & 13.37 \\
\hline
\end{tabular}

The Noor is located in the interval Intra El Wastini (I.E.W.) Formation to basal slump (B.S.). A) At position A, which is located in a distal position across the northern limb of the NDOA (Fig. 1B), the thickness change of the interval containing the Noor due to compaction was $19.62 \mathrm{~m}$. B) At position B, which is located in a proximal position along the northern limb of the NDOA (Fig. 1B), the thickness change of the interval containing the Noor due to compaction was $26.48 \mathrm{~m}$.

between the upper and middle reaches and is also coincident with a change of system trend from NNE to N (Fig. 8).

Middle Reach.-Over the first $2.25 \mathrm{~km}$ of the middle reach, the thalweg depth increases by $\sim 100 \mathrm{~m}(\sim 120 \mathrm{~ms})$, marking the face of the knickpoint (Fig. 6A). This coincides with the basinward limb of the faultparallel fold (Fig. 4). Across the knickpoint, relief of the basal erosion surface decreases by $\sim 20 \mathrm{~ms}(\sim 15 \mathrm{~m})$ (Fig. 6A), and at the downslope limit of the knickpoint the basal erosion surface shows a V-shaped crosssectional geometry (Fig. 10A, B). Downstream of the knickpoint face, over the remaining $15 \mathrm{~km}$ of the middle reach, the thalweg displays convex-up geometry (Fig. 6A) and the basal erosion surface is U-shaped (Fig. 10C, D). Over this convex-up section the basal erosion surface swings round the east-plunging nose of the NDOA (Fig. 8). An overall decline in relief (Fig. 6A) and width (Table 1) of the basal erosion surface is observed downslope through the middle reach, although a subtle increase in relief $(<15 \mathrm{~m})$ is observed at the point of maximum thalweg convexity ( $\mathrm{Y}$ in Fig. 6A). Basal erosion surface width is $\sim 3.5 \mathrm{~km}$ in the area of the knickpoint, decreasing to $2.5 \mathrm{~km}$ at the boundary with the lower reach (Table 1).

Lower Reach.-At the start of the lower reach, the eastern and western channel-levee complexes are observed ( $\mathrm{X}$ in Fig. 8B). The thalwegs of both exhibit concave-up geometry (Fig. 6). They display more irregular profiles compared to the single thalweg in the upper and middle reaches (Fig. 6A), which, in part, is due to difficulty in mapping the basal erosion surface over the region, related to changes in the underlying seismic facies. The thalweg of the younger, western channel-levee complex is, on average, located $150 \mathrm{~ms}(120 \mathrm{~m})$ above the thalweg of the eastern complex throughout the lower reach (Fig. 6A). At the start of the lower reach, basal erosion surface relief of the eastern channel-levee complex is $\sim 150 \mathrm{~ms}(120 \mathrm{~m})$ (Fig. 6A), and this declines downslope to a minimum of $\sim 100 \mathrm{~ms}(80 \mathrm{~m})$ (Fig. 6A). The average width of the basal erosion surface of the eastern channel-levee complex is $2.3 \mathrm{~km}$ (Table 1). It is possible to measure the relief of the western channel-levee complex only from $48 \mathrm{~km}$ downslope, where the thalweg has diverged sufficiently away from the eastern channel-levee complex to allow development of discrete flanks (Fig. 6A). At $48 \mathrm{~km}$, relief of the basal erosion surface of the western channel-levee complex is approximately $80 \mathrm{~ms}(65 \mathrm{~m})$, declining to $\sim 45 \mathrm{~ms}(35 \mathrm{~m})$ at $54 \mathrm{~km}$ (Fig. 6A). Downslope of $54 \mathrm{~km}$ the eastern flank of the western complex can no longer be measured as relief approaches zero (Figs. 6A, 11C, D).

In summary, the basal erosion surface is a U- to V-shaped, curvilinear, erosional unconformity $>55 \mathrm{~km}$ long, $\sim 50$ to $300 \mathrm{~m}$ deep and $<4 \mathrm{~km}$ wide (although width locally reaches $10 \mathrm{~km}$ in the upper reach due to concave-up flanks). Large, U- to V-shaped erosional unconformities at the bases of channel-levee systems have been referred to as erosional fairways (Deptuck et al. 2003), slope valleys (Samuel et al. 2003), or master bounding surfaces (Gee et al. 2007). In this study the erosional fairway term of Deptuck et al. (2003) is used.

\section{Top Surface}

The reflection mapped as the top surface was chosen based on its continuity along the length of the channel-levee system (Figs. 4, 5). Reflections above the top surface are observed to downlap onto it (Fig. 5). The continuity of the top surface across the slope and recognition of downlapping reflections suggests that it is a candidate maximum flooding surface.

\section{ARCHITECTURAL STYLE}

Several seismic facies that have a similar seismic character and/or spatial proximity to one another form a depositional element. Depositional elements comprise (1) channel and channel fill, (2) margin failure, (3) inner levees, (4) outer levees, (5) remobilized, and (6) abandonment.

Channel and channel fill, margin failure, and inner levee elements were all deposited in the channel-axis environment, confined by the erosional fairway. Outer levees and remobilized outer levees were deposited in the unconfined overbank environment. The abandonment element sits above the confined channel axis and the overbank deposits, and extends east- 


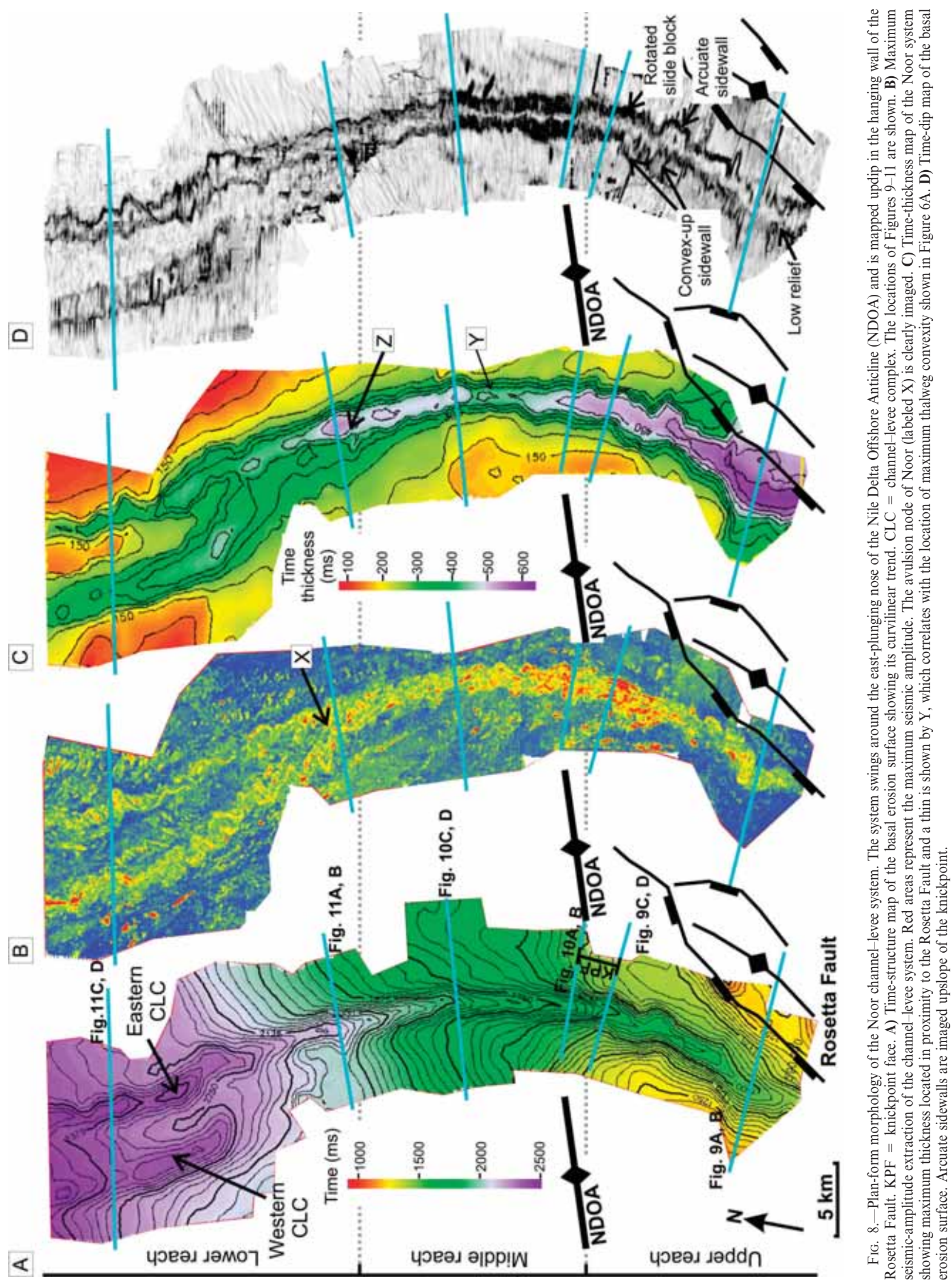



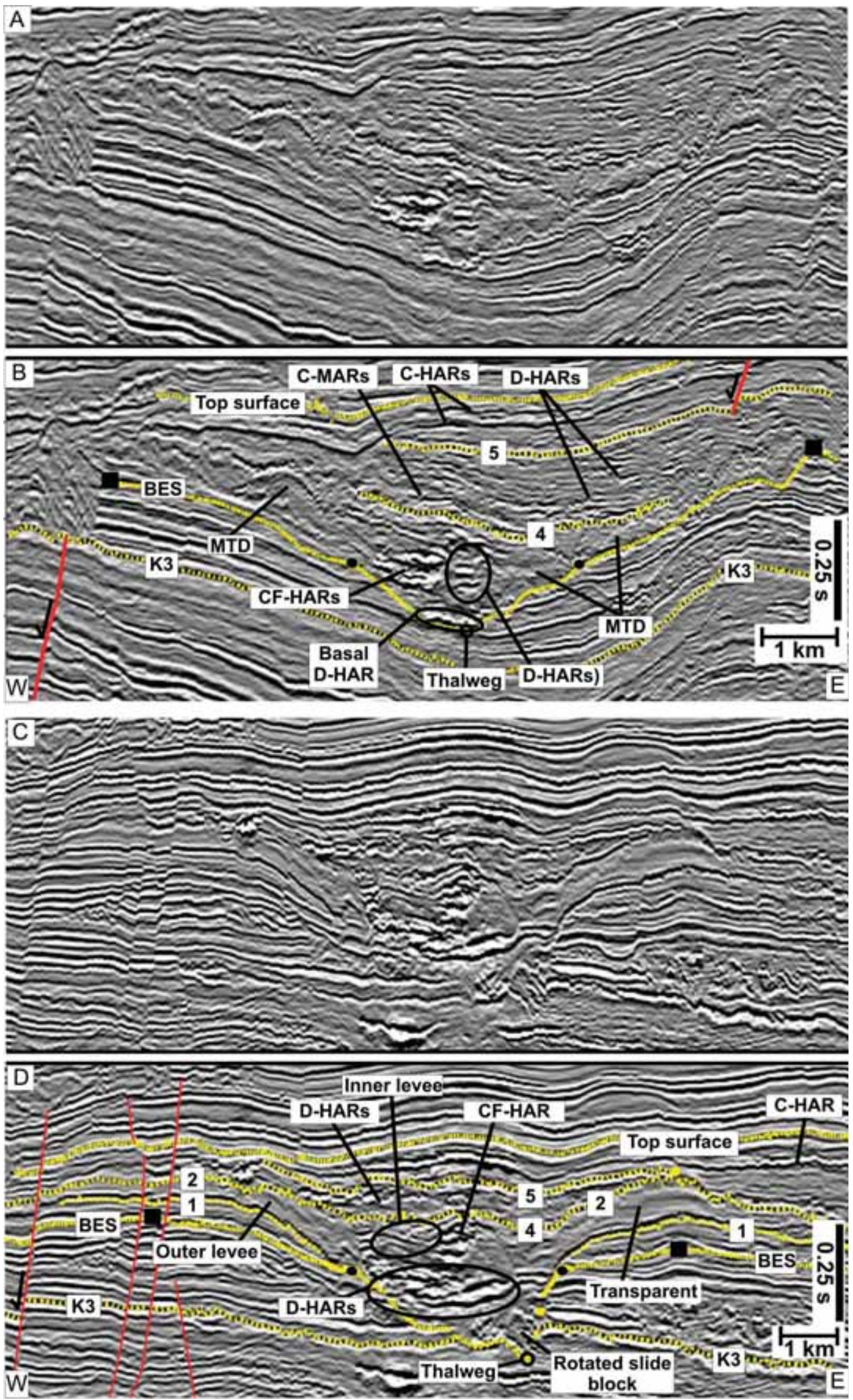
west across the Noor (Fig. 3). The abandonment element was partially confined by remaining accommodation (space for deposition; Vail 1987) created by an underfilled erosional fairway.

The architecture of each reach is described based on relationships between the depositional elements, and their relationship with the erosional fairway, top surface, and internal surfaces. In addition, measurements of several depositional elements are presented and a description of their stacking pattern is presented.

\section{Channel Axis Deposits}

Seismic Facies.-Channel axis deposits are characterized by highamplitude reflections (HARs). Several types of HARs are observed in the Noor channel axis: (1) a discontinuous basal HAR, (2) stacked discontinuous HARs, and (3) stacked discontinuous HARs with a channel-form cross-sectional geometry. HARs are believed to correspond to the thalweg (axial) deposits of channels (McHargue and Webb 1986; Deptuck et al. 2003). Where similar seismic facies have been calibrated using core, as in the Mississippi and Amazon fans, they have proved to be coarser-grained sediments (e.g., Bouma et al. 1985; Manley et al. 1997).

HARs Seismic Facies. - A basal discontinuous HAR $(<1 \mathrm{~km}$ wide $)$ immediately overlays the thalweg of the Noor channel-levee system over the first $10 \mathrm{~km}$ of the upper reach (Table 3A) (Figs. 4, 9A, B). Mayall et al. (2006), studying channel systems from West Africa, interpreted a basal discontinuous HAR as basal lag deposited by turbidity currents that largely bypass channel systems. Given that basal lags typically range from less than a meter to $5 \mathrm{~m}$ thick (Mayall et al. 2006) and the vertical resolution of the seismic data in this study is between 5 and $10 \mathrm{~m}$, it seems unlikely that the discontinuous basal HAR observed in the Noor channel-levee system directly images a discrete basal lag. Rather it represents the overall impedance contrast between a basal deposit (comprising the lag and/or initial coarse-grained channel fill), the overlying sediment, and sediment underlying the erosional fairway.

Stacked, discontinuous HARs (D-HARs) are predominantly located over the first $18 \mathrm{~km}$ of the Noor channel-levee system, confined by the sidewalls of the erosional fairway (Table 3A) (Figs. 9-11A, B). The maximum seismic amplitude extraction between isoproportional slices that intersect stacked D-HARs in the upper reach (Figs. 9C, D, 12E) shows that D-HARs often fill the entire width of the erosional fairway and show no sinuous plan-form geometry (Fig. 12E). Similar stacked discontinuous HARs identified in the Indus Fan have been interpreted to be coarse-grained thalweg deposits from laterally migrating channels that underwent little vertical aggradation (McHargue 1991). Although this interpretation may be applicable to the D-HARs in the Noor channellevee system, additional information (e.g., core data or higher-resolution seismic data) would be required to confirm this.

The third type of HARs seismic facies is characterized by a distinctive cross-sectional channel form (Table 3A) (Figs. 9, 10C, D, 11C, D). They comprise stacked D-HARs that widen upward and are flanked by a transparent to low-amplitude seismic facies (Fig. 9C, D) or stacked DHARs, which clearly sit within a channel-shaped erosion surface that truncates underlying reflections (Fig. 11C, D). Based on their channelshape cross-sectional morphology these seismic facies are termed channelform HARs (CF HARs). CF HARs range from 40 to $130 \mathrm{~m}$ in thickness and are generally 1 to $1.5 \mathrm{~km}$ wide, although they can reach $\sim 3 \mathrm{~km}$ wide in the lower reach (Table 1). CF HARs are observed along the length of the Noor channel-levee system occupying a progressively greater proportion of the channel axis environment downslope (Figs. 9-11). In the upper reach CF HARs are flanked by levees that are confined by the erosional fairway (inner levees; Fig. 9A, B). Throughout the middle and lower reaches CF HARs can be confined and unconfined by the erosional fairway (Figs. 10C, D, 11C, D). The latter are flanked by levees that are unconfined by the erosional fairway (outer levees; Figs. 10C, D, 11C, D). The maximum seismic amplitude extraction shown in Figures 12B and 12C images CF HARs located in the distal middle reach and lower reach that in cross section show a multistory and laterally offset stacking pattern (Figs. 10C, D, 11C, D). In the distal middle reach the plan-form morphology of the CF HARs is observed to be patchy with no clearly distinguishable sinuous features (Fig. 12C). By contrast in the lower reach, CF HARs show sinuous geometries and are clearly laterally offset towards the east (Fig. 12B).

Based on their cross-sectional stacking pattern and plan-form geometry the channel-form HARs are interpreted to represent the cut, fill, and relative abrupt relocation of channels within the channel belt leading to lateral stepping of a meander loop (Figs. 11C, D, 12B). The relocation is considered abrupt relative to channels characterized by the deposition of lateral accretion packages (e.g., Abreu et al. 2003). Abrupt relocation of channels has been observed in the Indus fan and interpreted to have been a result of a widening through time of the channel belt and movement of erosive flows towards the outer side of the bend that eventually cut a new channel (plugand-cut of Deptuck et al. 2007). The stacked D-HARs associated with the CF HARs are interpreted to represent impedance contrasts within the aggradational fill of individual channels in the channel belt.

In summary, the HARs seismic facies in the Noor channel-levee system are located within the confines of the erosional fairway or between levees. All of them are interpreted as being related to channels or channel fill and hence form the channel and channel-fill depositional element.

Channel Stacking Patterns.-A systematic change of stacking pattern of the CF HARs is observed downslope. In the upper reach and proximal $3 \mathrm{~km}$ of the middle reach, only isolated CF HARs are observed (Fig. 9). In the distal middle reach, multistory CF HARs with a component of lateral offset are observed, largely confined by outer levees (Fig. 10C, D). In the distal lower reach, both the eastern and western channel-levee complexes are characterized by multistory CF HARs with a component of lateral offset that are confined by the erosional fairway as well as by outer levees (Fig. 11C, D).

Non HARs Seismic Facies.-Three seismic facies not characterized by HARs are identified in the channel-axis environment. At the base, immediately above the thalweg or located alongside the sidewalls of the basal erosion surface, two seismic facies are identified: (1) subparallel, medium-amplitude reflections inclined towards the sidewalls, and (2)

\section{$\leftarrow$}

FIG. 9.-Architectural style of the Noor channel-levee system and morphology of the basal erosion surface through the upper reach. A) Uninterpreted seismic cross section across the proximal upper reach. B) Interpreted seismic cross section shown in part A indicating the seismic facies, basal erosion surface, top surface, and mapped internal surfaces. C) Uninterpreted seismic cross section across the distal upper reach. D) Interpreted seismic cross section shown in part C indicating the seismic facies, basal erosion surface, top surface, and mapped internal surfaces. BES = basal erosion surface, MTD = mass-transport deposit, K3 = the reflection truncated by the thalweg of the basal erosion surface in the upper reach (Fig. 4B). HARs = high-amplitude reflection, MARs $=$ medium-amplitude reflection, D $=$ discontinuous, $\mathrm{C}=$ continuous, $\mathrm{CF}=$ channel-form. Surface 2 demarcates the top of a transparent seismic facies interpreted as an outer levee. Surface 4 marks the base of the abandonment deposits, and surface 5 marks the base of the prodelta environment. Solid circles mark the inflection points, and solid squares mark the shallowest point of the flank used to measure the relief of the basal erosion surface. This figure is in color in the on-line version. 

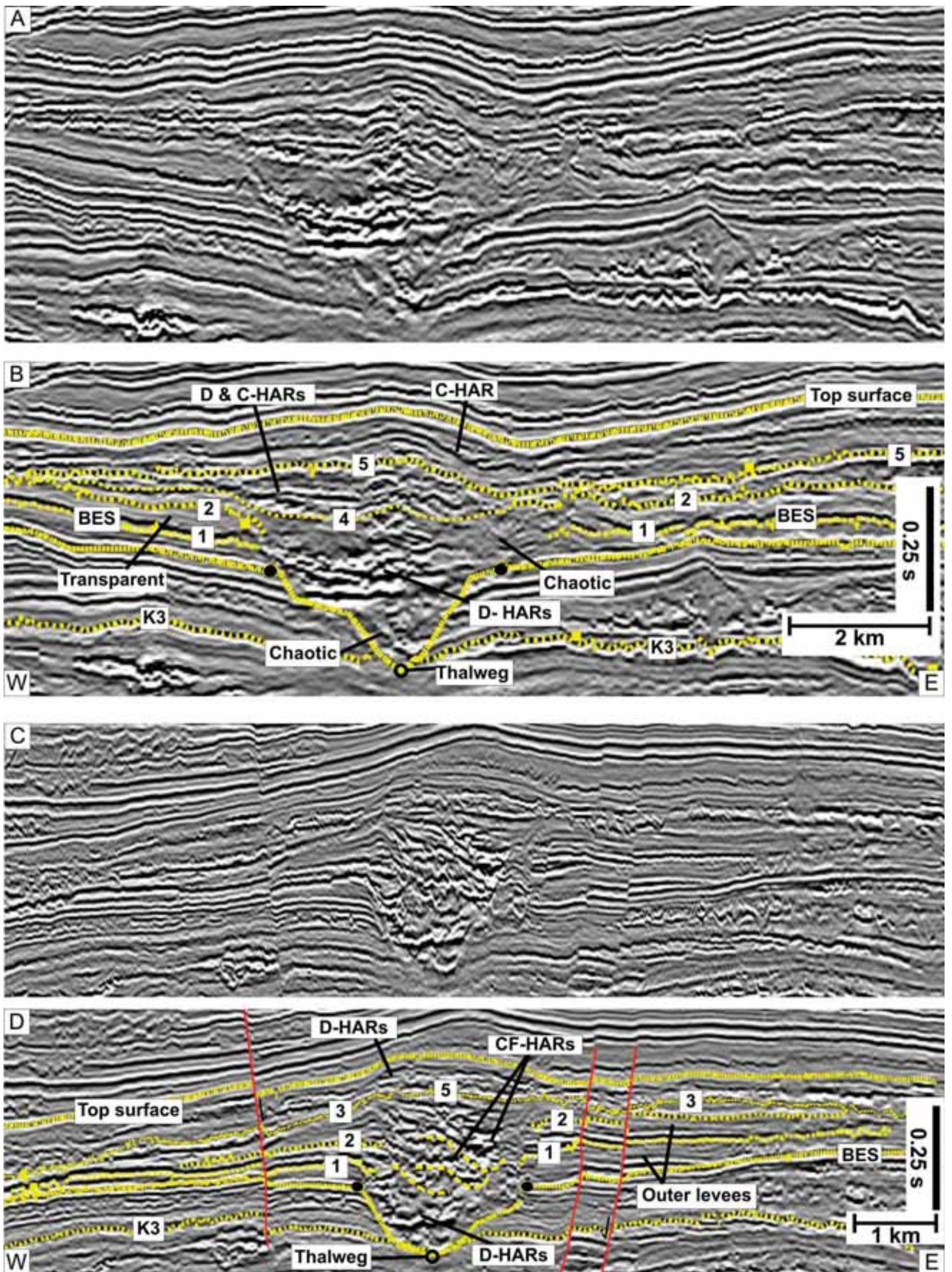
chaotic, low- to medium-amplitude reflections (Table 3A). Both seismic facies have a limited downslope extent and are most prominent in the distal part of the upper reach, immediately upslope of the knickpoint, where they coincide with the maximum relief of the basal erosion surface and arcuate sidewalls (Figs. 8D, 9C, D).

Based on the inclination of the subparallel reflections towards the sidewalls of the basal erosion surface and the relationship to the arcuate sidewalls, these seismic facies are interpreted as rotational slide blocks developed through sidewall failure due to oversteepening or undercutting by gravity flows. The proximity of the chaotic seismic facies to the rotated slide blocks, arcuate sidewalls, and their limited downslope extent $(\sim<2 \mathrm{~km})$ support an interpretation of formation through failure of the margins of the erosional fairway and remobilization. Since the rotated slide block and remobilized seismic facies are interpreted to have been deposited by a similar sedimentary process, together they form the margin-failure depositional element.

The remaining non-HARs related seismic facies is a wedge-shaped unit of medium-amplitude, subparallel, continuous reflections that thins away from channel and channel-fill depositional elements (Table 3A). These are located in the upper reach, towards the top of the channel-axis environment, alongside channel-form HARs and are confined by outer levees (Fig. 9C, D). The wedge shape is indicative of a levee. These levees are interpreted as inner levees on the basis of their location adjacent to $\mathrm{CF}$ HARs and between outer levees, and are similar to the inner levees described by Deptuck et al. (2003) from the Indus fan and the low levees of Piper et al. (1999) from the Hueneme submarine fan. Inner levees have been suggested to form through overbank sedimentation from channels located in an erosional fairway (Deptuck et al. 2003). Inner levees are observed only in the distal upper reach of the Noor channel-levee system, where their location coincides with the area of greatest relief of the basal erosion surface ( 280 m Fig. 6A) (Fig. 9C, D).

\section{Overbank Deposits}

Seismic Facies.-The overbank environment is characterized by the following seismic facies: (1) chaotic reflections of variable seismic amplitude (Fig. 9A, B), (2) transparent units (Fig. 9C, D), and (3) continuous reflections of variable seismic amplitude that converge away from the channel axis (Table 3B) (Figs. 10C, D, 11).

Based on the seismic character and location in the overbank environment, the chaotic seismic facies are interpreted to have developed from localized post-depositional remobilization of overbank deposits and are termed the remobilized overbank depositional element. These deposits may be remobilized sediment, which was initially deposited by the overbank sedimentation of turbidity currents from the confines of the erosional fairway (i.e., outer levees) or unrelated to overbank sedimentation and remobilized adjacent prodelta deposits. The transparent unit is interpreted as outer levee based on its location directly on the flanks of the basal erosion surface and thickening towards the channel axis (Fig. 9C, D). Based on their cross-sectional shape and location above the flanks of the basal erosion surface, the continuous reflections of variable seismic amplitude that converge away from the channel axis are further interpreted as outer levees. These levees are comparable to the "high levees" of Piper et al. (1999), the "master bounding levees" of Posamentier (2003), and the "outer levees" of Deptuck et al. (2003).

The presence of these depositional elements in the overbank environment changes successively downslope. The remobilized deposits are observed over the first $8 \mathrm{~km}$ (Fig. 5). At $8 \mathrm{~km}$ the remobilized deposits truncate outer levee (Fig. 5). From 8 to $\sim 25 \mathrm{~km}$, the overbank environment is characterized by the transparent outer levee (Figs. 9C, D, $10 \mathrm{~A}, \mathrm{~B})$ and from $25 \mathrm{~km}$, until the northern edge of the dataset three outer levee units, which are recognized based on a vertical change of seismic amplitude, are observed (Figs. 10C, D, 11). These units are defined by mapped internal surfaces 1 to 3 (Figs. 10C, D, 11C, D). The two oldest internal surfaces, 1 and 2, have tentatively been mapped upslope into the upper reach (Figs. 5, 9C, D). This mapping is tentative, because the seismic amplitude between the erosional fairway and internal surface 1, and between internal surfaces 1 and 2, changes downslope as the Noor channellevee system crosses the fault-parallel fold (Fig. 5). In the upper reach the seismic facies between internal surfaces 1 and 2 is transparent (Fig. 9C, D), becoming high amplitude in the middle reach (Fig. 10C, D). The downchannel change of seismic amplitude may represent a downslope or temporal evolution of flow properties (e.g., grain size).

In the distal middle and lower reaches of the Noor channel-levee system the outer levees are located alongside channel-form HARs (Fig. 10C, D). This contrasts with outer levees observed in the Indus fan and the Arabian Sea (Deptuck et al. 2003) and in the Gulf of Mexico (Posamentier 2003), which are located alongside inner levees rather than channels and channel-fill elements. Unfortunately, in the Noor channellevee system, is has not been possible to determine the timing relationship between the outer levees and development of the channel-form HARs.

The time-dip map of internal surface 1 through the lower reach reveals a series of bed forms with crests orientated $40^{\circ}$ to the Noor thalweg (Fig. 13). A dip section across these bed forms reveals that they stack upslope (Fig. 13D). Based on their upslope stacking character and location in an outer levee they are interpreted as sediment waves (c.f. Migeon et al. 2001; Wynn and Stow 2002). The orientation of these sediment waves with respect to the Noor suggests that a component of overbank sedimentation trended oblique to the Noor thalweg.

Quantification.-The depths of the outer levee crests were measured downslope of $25 \mathrm{~km}$ (between 25 and $45 \mathrm{~km}$; Fig. 6B). Uncertainties associated with correlation of internal surfaces 1 and 2 and the potential diachronous nature of the outer levees upslope of $25 \mathrm{~km}$ prevents accurate measurement of levee thickness. The thickness of the eastern outer levee units 2 and 3 cannot be assessed downslope of 35 and $38 \mathrm{~km}$ respectively since they are eroded by a mass-transport complex (Fig. 5).

The eastern, outer levee units are always thicker than the western, and the thickness of several outer levee units increases downslope (Table 1) (Fig. 6B). The average thickness of all three western outer levees increases by at least $15 \mathrm{~m}$ downslope from the distal middle to the proximal lower reach (Table 1). From the middle to lower reach, the eastern outer levee 1 thickens downslope by a minimum of $55 \mathrm{~m}$ (Table 1) (Fig. 6B).

FIG. 10.-Architectural style of the Noor channel-levee system and morphology of the basal erosion surface through the middle reach. A) Uninterpreted seismic cross section across the proximal middle reach. B) Interpreted seismic cross section shown in part A indicating the seismic facies, basal erosion surface, top surface, and mapped internal surfaces. C) Uninterpreted seismic cross section across the distal middle reach. D) Interpreted seismic cross section shown in part $\mathrm{C}$ indicating the seismic facies, basal erosion surface, top surface, and mapped internal surfaces. Note the multistory stacking pattern of the CF-HARs with a component of lateral migration. $\mathrm{BES}=$ basal erosion surface, $\mathrm{K} 3=$ the reflection truncated by the thalweg of the basal erosion surface in the upper reach (Fig. $4 \mathrm{~B})$. HARs $=$ high-amplitude reflection, $\mathrm{D}=$ discontinuous, $\mathrm{C}=$ continuous, $\mathrm{CF}=$ channel-form. Surfaces 1,2 , and 3 demarcate the top of the outer levees. Surface 4 marks the base of the abandonment deposits, and surface 5 marks the base of the prodelta environment. Solid circles mark the inflection points used to measure the relief of the basal erosion surface. This figure is in color in the on-line version. 

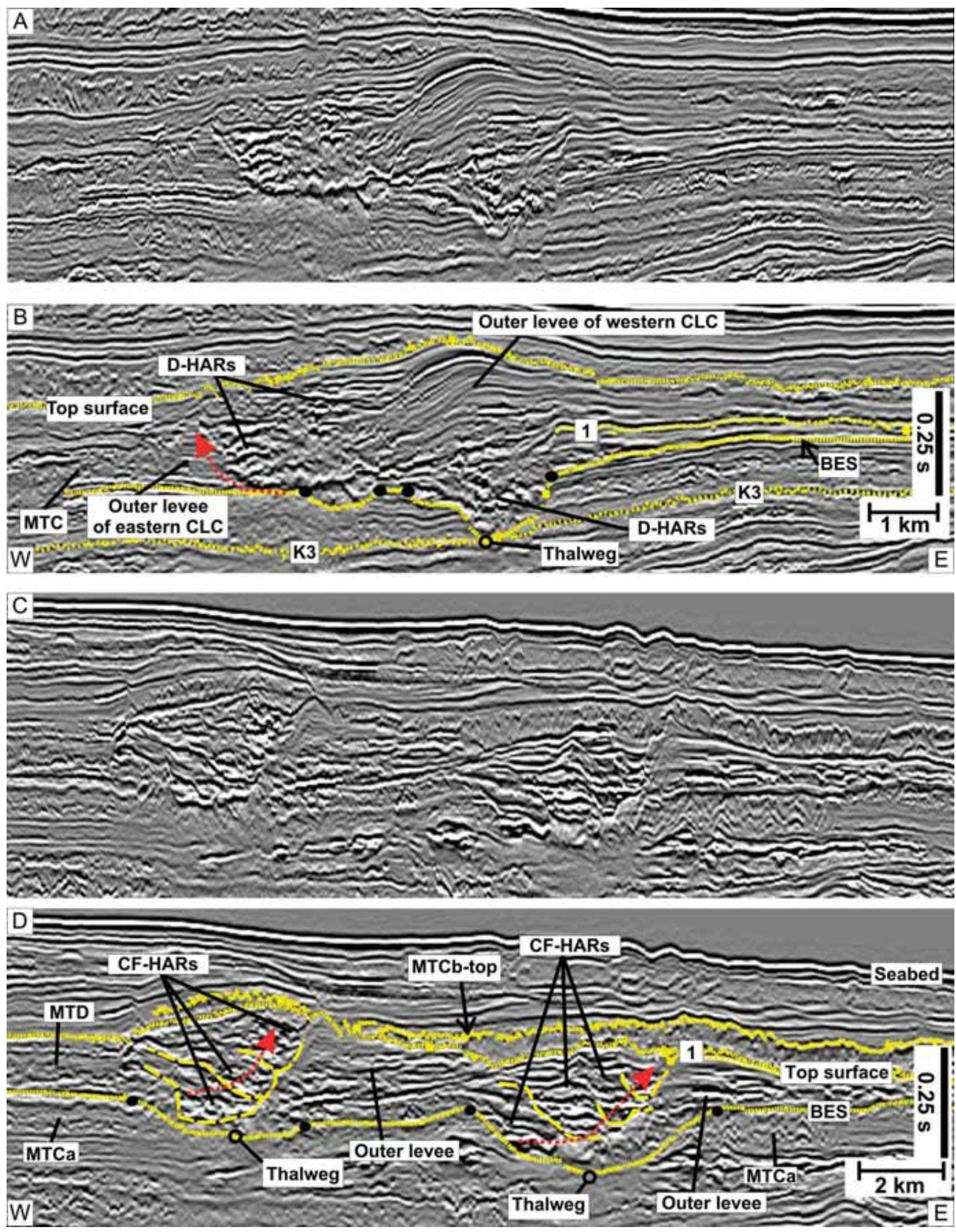
TABLE 3A.- Seismic facies of the Noor channel-levee system. Based on an interpretation of the sedimentary processes responsible for deposition of the facies, each facies is interpreted as a depositional element. The following seismic facies comprise the channel and channel-fill elements: basal discontinuous high-amplitude reflection (D-HAR), stacked discontinuous HARs (D-HARs), channel-form HARs (CF HARs). The inner-levee and margin-failure depositional elements are also shown. BES = basal erosion surface.

\begin{tabular}{|c|c|c|c|c|c|c|}
\hline $\begin{array}{l}\text { A } \\
\text { Example }\end{array}$ & & & 5 levees & & & \\
\hline Amplitude & High & High & High & Medium & Medium & Low to medium \\
\hline $\begin{array}{l}\text { Reflection } \\
\text { continuity }\end{array}$ & Discontinuous & Discontinuous & Discontinuous & Continuous & Discontinuous & Discontinuous \\
\hline $\begin{array}{l}\text { Internal } \\
\text { geometry }\end{array}$ & Sub horizontal & $\begin{array}{l}\text { Sub horizontal, } \\
\text { parallel }\end{array}$ & $\begin{array}{l}\text { Sub parallel, sub } \\
\text { arcuate }\end{array}$ & $\begin{array}{l}\text { Sub parallel, } \\
\text { inclined }\end{array}$ & $\begin{array}{l}\text { Parallel and tilted towards sidewalls } \\
\text { of the BES }\end{array}$ & Chaotic \\
\hline $\begin{array}{l}\text { External } \\
\text { geometry }\end{array}$ & Sub horizontal & Sub horizontal & U-shaped & Wedge & Tabular & Chaotic \\
\hline Distribution & $\begin{array}{l}\text { Located along } \\
\text { thalweg, over the } \\
\text { first } 10 \mathrm{~km} \text { of the } \\
\text { upper reach }\end{array}$ & $\begin{array}{l}\text { Upper reach: } \\
\text { confined by basal } \\
\text { erosion } \\
\text { surface (BES). } \\
\text { Middle reach: } \\
\text { confined by BES and } \\
\text { between outer levees }\end{array}$ & $\begin{array}{l}\text { Upper reach: } \\
\text { isolated and } \\
\text { confined by inner } \\
\text { levees. Middle and } \\
\text { lower reaches: } \\
\text { confined by BES } \\
\text { and outer levees }\end{array}$ & $\begin{array}{l}\text { Distal upper reach } \\
\text { where they lie } \\
\text { alongside channel } \\
\text { d form HARs }\end{array}$ & $\begin{array}{l}\text { Distal upper reach: adjacent to } \\
\text { sidewalls, located at the base of the } \\
\text { l-channel axis and with limited spatial } \\
\text { extent }\end{array}$ & $\begin{array}{l}\text { Upper reach: located at the base of } \\
\text { the channel axis and in proximity to } \\
\text { the rotated slide blocks and arcuate } \\
\text { sidewalls }\end{array}$ \\
\hline $\begin{array}{l}\text { Process } \\
\text { interpretation }\end{array}$ & $\begin{array}{l}\text { The basal D-HAR } \\
\text { is interpreted as a } \\
\text { lag and coarser- } \\
\text { grained channel } \\
\text { fill within an } \\
\text { erosional fairway }\end{array}$ & $\begin{array}{l}\text { D-HARs are } \\
\text { interpreted as } \\
\text { channels within an } \\
\text { erosional fairway }\end{array}$ & $\begin{array}{l}\text { Channel-form } \\
\text { HARs are } \\
\text { interpreted as } \\
\text { sinuous channels } \\
\text { within an erosional } \\
\text { fairway that cut, } \\
\text { fill and abruptly } \\
\text { relocate laterally }\end{array}$ & $\begin{array}{l}\text { Interpreted as } \\
\text { inner levees }\end{array}$ & $\begin{array}{l}\text { Interpreted as a rotated slide block } \\
\text { which formed through collapse of the } \\
\text { sidewalls of the BES }\end{array}$ & $\begin{array}{l}\text { Interpreted to have formed through } \\
\text { failure of the sidewalls of the BES } \\
\text { with remobilization producing a } \\
\text { chaotic internal reflection character. }\end{array}$ \\
\hline $\begin{array}{l}\text { Depositional } \\
\text { element }\end{array}$ & $\begin{array}{l}\text { Channel and } \\
\text { channel fill }\end{array}$ & $\begin{array}{l}\text { Channel and channel } \\
\text { fill }\end{array}$ & $\begin{array}{l}\text { Channel and } \\
\text { channel fill }\end{array}$ & $\begin{array}{l}\text { Channel and } \\
\text { channel fill }\end{array}$ & Margin failure & Margin failure \\
\hline
\end{tabular}

Although it has dominantly been reported from other submarine channels that levees thin downslope (e.g., Pirmez and Flood 1995; Babonneau et al. 2002; Skene et al. 2002), a recent study of channel-levee systems located offshore Trinidad and Tobago documented downslope levee thickening attributed to tilting of the seafloor resulting in an increase of overbank sedimentation over one side of the channel-levee system (Wood and Mize-Spanksy 2009). Preferential overbank deposition on one side of a channel-levee system cannot explain the observed downslope levee thickening on both sides of the Noor. Furthermore, preferential overbank deposition cannot explain how the normal downslope loss of sediment due to overspill can be overcome (Pirmez and Imran 2003). Levee architecture is intimately linked to channel width and depth (Skene et al. 2002; Keevil et al. 2007), and slope (Keevil et al.
2007). Relationships between levees, the width and depth of the erosional fairway, and thalweg slope of the Noor are explored in the discussion to attempt to account for this unusual process.

Apparent downslope levee thickening related to the downslope decline of overburden thickness causing a downslope decrease of levee compaction is considered. At two positions, $20 \mathrm{~km}$ apart, located on the northern limb of the NDOA the results of depth conversion and decompaction are presented (Table 2). The change of thickness of the interval containing the Noor (I.E.W. to B.S; Fig. 7), at positions A and B, due to compaction was $19.5 \mathrm{~m}$ and $26.5 \mathrm{~m}$ respectively (Table 2). Therefore, due to compaction, the thickness of the interval containing the Noor changed by $7 \mathrm{~m}$ from position A (downslope) to B (upslope). Since downslope levee thickening between 15 to $55 \mathrm{~m}$ has been identified, a $7 \mathrm{~m}$ change of sediment thickness between

Fig. 11.-Architectural style of the Noor channel-levee system and morphology of the basal erosion surface through the lower reach. A) Uninterpreted seismic cross section across the proximal lower reach. B) Interpreted seismic cross section shown in part A indicating the seismic facies, basal erosion surface, top surface, and mapped internal surfaces. The eastern outer levee of the western channel-levee complex drapes the eastern channel-levee complex (CLC), indicating that the avulsion took place as the eastern CLC was abandoned. C) Uninterpreted seismic cross section across the distal lower reach. D) Interpreted seismic cross section shown in part C indicating the seismic facies, basal erosion surface, top surface, and mapped internal surfaces. CF-HARs are multistory with a component of lateral migration. MTCb erodes the top of the Noor channel-levee system, and the base of Noor erodes into MTCa. No outer levee is observed above the western flank of the western channel-levee complex (CLC), where instead an MTD (remobilization of outer levees) is observed. BES = basal erosion surface, K3 = the reflection truncated by the thalweg of the basal erosion surface in the upper reach (Fig. 4B). HARs = high-amplitude reflection, D = discontinuous, $\mathrm{CF}=$ channel-form, MTC = mass-transport complex, MTD = masstransport deposits (remobilization of outer levees). Surface 1 demarcates the top of outer levee 1. Solid circles mark the inflection points used to measure the relief of the basal erosion surface. This figure is in color in the on-line version. 


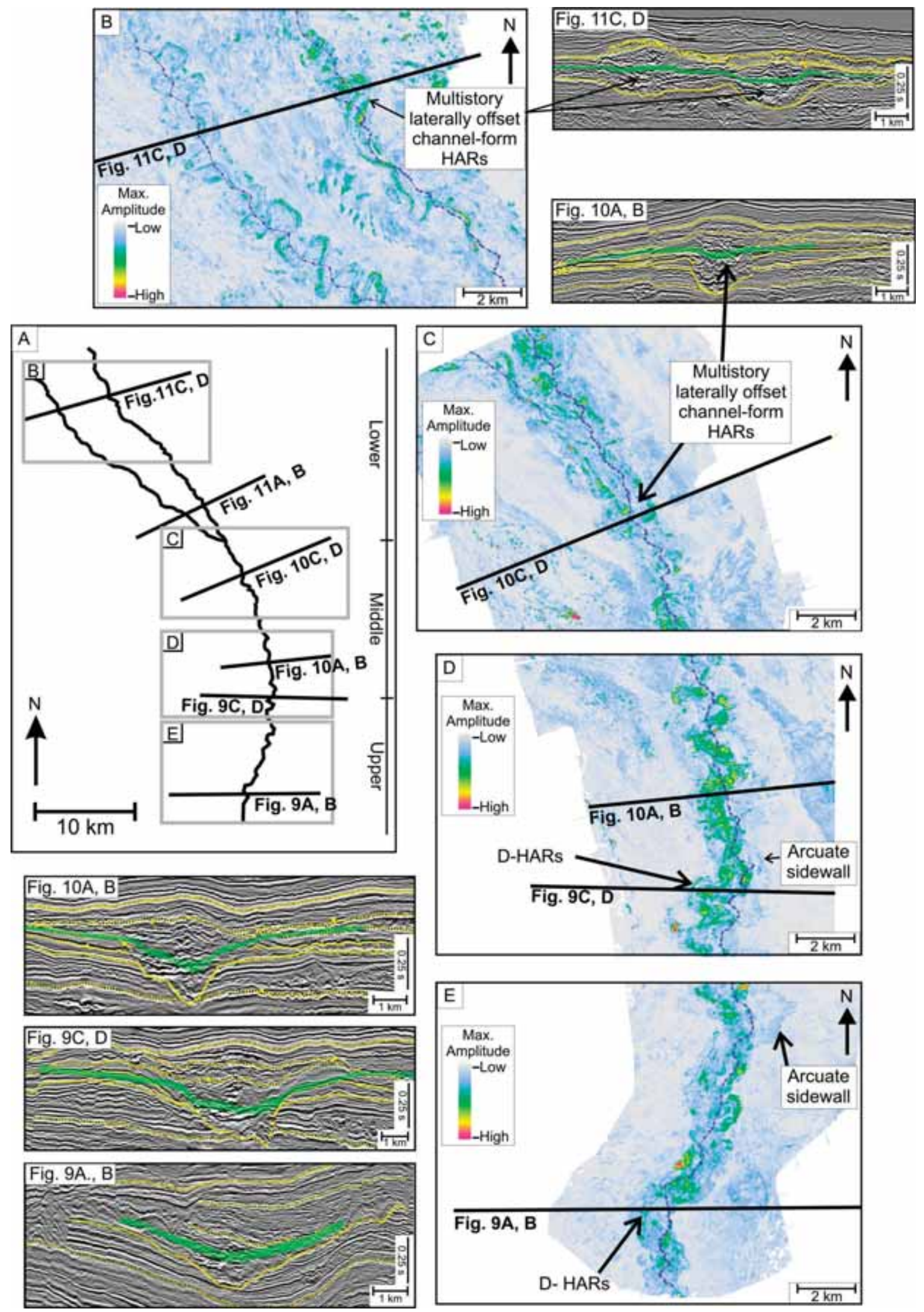


TABLE 3B.-Seismic facies in the overbank, abandonment, and prodelta environments. Based on an interpretation of the sedimentary processes responsible for deposition of the facies, each facies is interpreted as a depositional element. BES = basal erosion surface. Three outer levees are identified by vertical changes of seismic amplitude. In the lower reach, where the prodelta deposits thicken above the thinnest parts of the outer levees, the levees have been remobilized.

\begin{tabular}{|c|c|c|c|c|}
\hline $\begin{array}{l}\text { B } \\
\text { Example }\end{array}$ & $\begin{array}{l}\text { Outer levee } 120 \\
\text { Outer levee } 2 \\
\text { Outer levee } 3\end{array}$ & 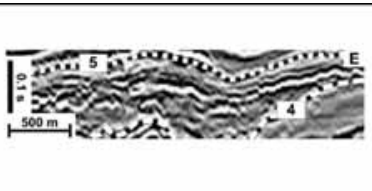 & Top surface Imbricate & Top surface \\
\hline Amplitude & Varies from transparent to high & Low to high & High & Low to high \\
\hline $\begin{array}{l}\text { Reflection } \\
\text { continuity }\end{array}$ & Continuous & Continuous to discontinuous & Continuous to discontinuous & $\begin{array}{l}\text { Continuous in cross section and } \\
\text { discontinuous downslope as they } \\
\text { show downlap termination }\end{array}$ \\
\hline $\begin{array}{l}\text { Internal } \\
\text { geometry }\end{array}$ & $\begin{array}{l}\text { Parallel, converging away from } \\
\text { channel system. }\end{array}$ & Chaotic & Parallel, inclined, and imbricated & Folded \\
\hline $\begin{array}{l}\text { External } \\
\text { geometry }\end{array}$ & $\begin{array}{l}\text { Wedge (cross sectional) in middle } \\
\text { and lower reaches }\end{array}$ & $\begin{array}{l}\text { Thickens across the top of the } \\
\text { channel axis environment and } \\
\text { upslope. Low-amplitude folding }\end{array}$ & $\begin{array}{l}\text { Thickens above the thinnest parts of } \\
\text { the outer levees }\end{array}$ & $\begin{array}{l}\text { Lenticular in cross section. Low- } \\
\text { amplitude folding. Thickens } \\
\text { upslope }\end{array}$ \\
\hline Distribution & $\begin{array}{l}\text { Above flanks. Upper reach: lie } \\
\text { alongside inner levees. Middle and } \\
\text { lower reaches: lie alongside sinuous } \\
\text { channels }\end{array}$ & First $8 \mathrm{~km}$ of the upper reach. & $\begin{array}{l}\text { Middle and lower reach: top of } \\
\text { succession. Lower reach: truncated } \\
\text { by a mass-transport complex }\end{array}$ & $\begin{array}{l}\text { Throughout the Noor, except in the } \\
\text { lower reach, where it is eroded by a } \\
\text { mass transport complex }\end{array}$ \\
\hline $\begin{array}{l}\text { Process } \\
\text { interpretation }\end{array}$ & $\begin{array}{l}\text { Interpreted as outer levees based on } \\
\text { their wedge-shaped cross sectional } \\
\text { geometry and location above the } \\
\text { BES. Outer levees } 1,2 \text {, and } 3 \\
\text { represent different units that are } \\
\text { differentiated based on a vertical } \\
\text { change of seismic amplitude }\end{array}$ & $\begin{array}{l}\text { Filling of remaining } \\
\text { accommodation space prior to } \\
\text { abandonment by deposits of gravity } \\
\text { currents and hemipelagic fallout (cf. } \\
\text { abandonment successions cored by } \\
\text { Samuel et al. } 2003 \text { and Cross et al. } \\
\text { 2009). }\end{array}$ & $\begin{array}{l}\text { These reflections are part of the } \\
\text { prodelta environment. Their } \\
\text { inclined and imbricated internal } \\
\text { geometry suggests that the parts of } \\
\text { the prodelta infilling remnant } \\
\text { topography above the outer levees } \\
\text { were remobilized }\end{array}$ & $\begin{array}{l}\text { Progradational reflections that } \\
\text { downlap onto the abandonment, } \\
\text { overbank, and channel-axis deposits } \\
\text { are interpreted as prodelta deposits. }\end{array}$ \\
\hline $\begin{array}{l}\text { Depositional } \\
\text { element }\end{array}$ & Outer levee & Abandonment & Prodelta & Prodelta \\
\hline
\end{tabular}

positions A and B indicates that the downslope levee thickening observed along Noor was related to syndepositional processes and not an apparent thickening related to an increase of postdepositional compaction upslope as overburden thickness increases.

\section{Abandonment Deposits}

Seismic Facies.-The abandonment depositional environment is characterized by medium-amplitude continuous reflections (Fig. 9A, B) and high-amplitude discontinuous reflections (Table 3B) (Figs. 9C, D, $10 \mathrm{~A}, \mathrm{~B})$. The base and top of this environment are demarcated by two mapped internal surfaces, numbered 4 and 5 respectively (Figs. 9, 10A, B). Both internal surfaces demarcate a vertical change of seismic facies. The basal internal surface (4) separates the HARs seismic facies of the channel and channel-fill element, and the chaotic and continuous reflections of the remobilized and outer levee elements from the abandonment deposits (Fig. 9). The upper internal surface (5) separates the abandonment deposits from overlying high-amplitude continuous reflections which downlap onto the top surface (internal surface 5) of the abandonment environment (Figs. 5, 9). The abandonment deposits thicken upslope (Fig. 5).

A similar upslope thickening of deposits has been identified in Pliocene channels in the Nile Delta and interpreted to represent an abandonment succession, related to the final stages of the fill of an erosional fairway (Cross et al. 2009). The Pliocene abandonment deposits consist of mudstones, siltstones, and minor thin-bedded sands (Cross et al. 2009); however, no core data are available in the Noor.

\section{Prodelta Deposits}

Seismic Facies.-A package of progradational, high-amplitude reflections that downlap onto the abandonment, overbank, and channel-axis deposits are interpreted as prodelta deposits (Figs. 4, 5). In cross section

FIG. 12._Plan-form geometry of the channel and channel-fill depositional elements. A) Map showing the locations of the area covered by the maximum-seismic amplitude extractions and Figures 9 to 11. B) Maximum seismic-amplitude extraction between two isoproportional slices in the lower reach of Noor. The location of the isoproportional slices are demarcated in green on the seismic cross sections. CF-HARs are offset to the east, causing the meander bend to migrate laterally. C) Maximum seismic-amplitude extraction between two isoproportional slices located in the middle reach. Note the fragmented character and lack of sinuosity of the channel and channel-fill elements within the erosional fairway. D) Maximum seismic amplitude extraction between two isoproportional slices located across the middle and distal upper reaches. The isoproportional volume intersects stacked discontinuous, high-amplitude reflections (D-HARs) that occupy the entire width of the erosional fairway. Note their sinuous plan-form geometry, which is much wider than the CF HARs in the lower reach (part B). E) Maximum-seismic amplitude extraction between two isoproportional slices located in the upper reach of Noor. As in part D, stacked D-HARs are intersected by the isoproportional volume to show that they fill a large portion of the width of the erosional fairway. 

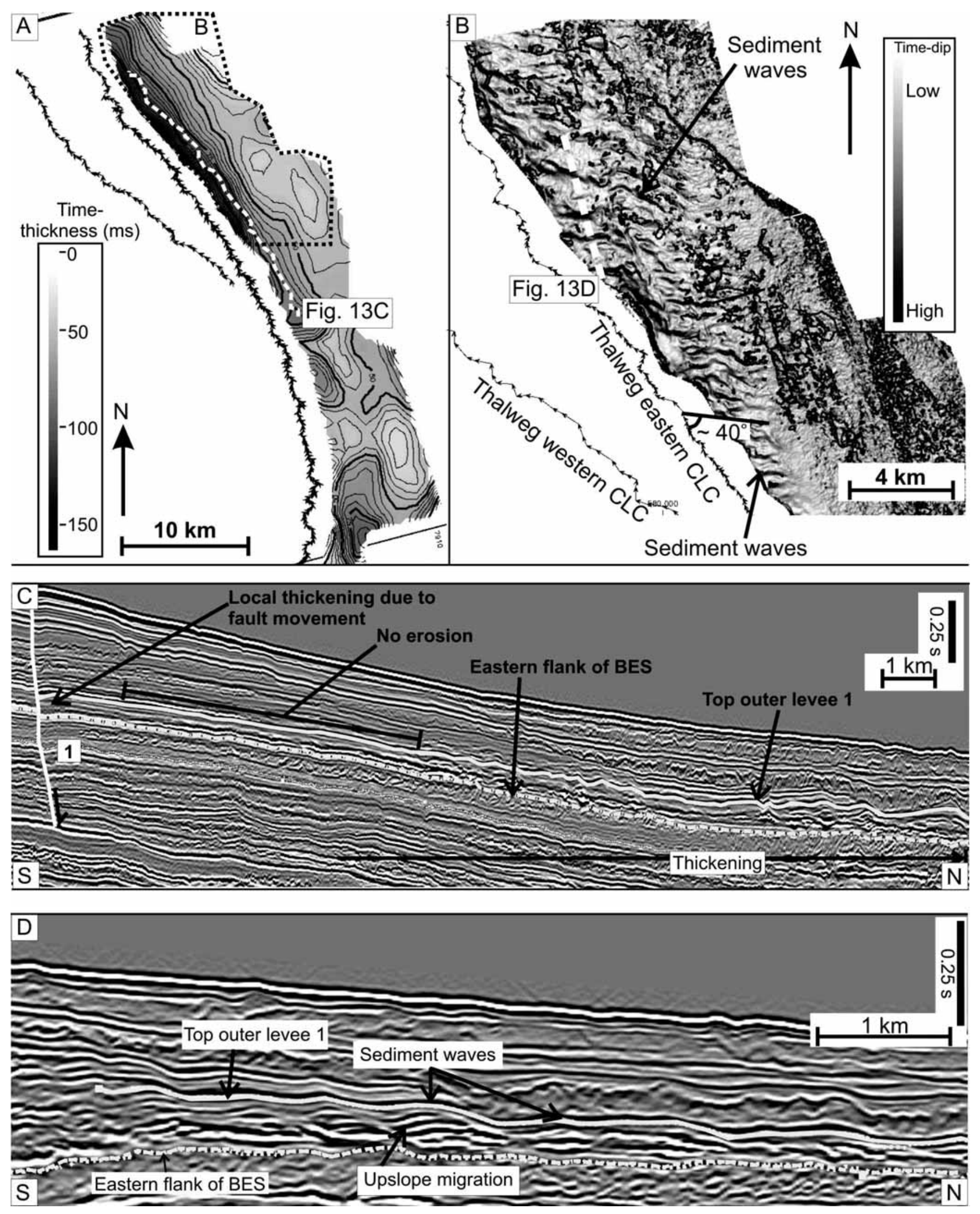
(E-W) these high-amplitude reflections are continuous across the Noor system in the upper and proximal middle reaches (Table 3B) (Figs. 9, $10 \mathrm{~A}, \mathrm{~B}$,$) . In the distal lower reach they are discontinuous, characterized$ by imbricate geometries, and they thicken above the thinnest parts of the underlying levee deposits in the distal middle reach (Table 3B) (Fig. 10C, D). Based on the observed change in thickness, prodelta deposits are interpreted to have infilled remnant topography above the abandoned Noor system.

\section{DEFORMATION}

Several observations suggest that the Noor channel-levee system developed during a time of activity on the Rosetta Fault, NDOA, and the fault-parallel fold. These observations are: (1) local thickness variations of the seismic interval containing the Noor channel-levee system in the hanging wall of the Rosetta Fault (Fig. 14A), (2) systematic changes in the trend of the channel-levee system with respect to the Rosetta Fault, NDOA and fault-parallel fold (Figs. 1, 8, 14A), and (3) erosional truncation beneath the Noor coincident with the hinge of the faultparallel fold (Fig. 4B).

Pre-Noor Deformation.-The gross interval isochron that contains the Noor channel-levee system shows an elongate sediment thick in the immediate hanging wall of the Rosetta Fault and trending parallel to the fault (Fig. 14A). The sediment thick is $<20 \mathrm{~km}$ wide and extends $<10 \mathrm{~km}$ north of the central part of the Rosetta Fault, where it is observed to thin (Fig. 14A). This thickened sediment package is coincident with the synform geometries observed in the hanging wall of the Rosetta Fault (Fig. 14B, C).

The location and plan-form geometry of the sediment thick indicates that structural movement, associated with the Rosetta Fault, was responsible for accommodation generation in the immediate hanging wall and due to a reduction of lateral tilt away from the fault, thinning to the north. Based on the spatial relationship between the thickened area and the Rosetta Fault it is suggested that structural movement on the Rosetta Fault influenced seafloor topography and, subsequently, deposition. The thinner area to the north represents the fault-parallel fold that is defined by a $\mathrm{N}$ to $\mathrm{S}$ change of seafloor dip direction (Fig. 14A). Towards the south of the fault-parallel fold, the seafloor dipped towards the Rosetta Fault and to the north of the fold; as the influence of the Rosetta Fault declined, the seafloor dipped to the north (Fig. 14A). Based on the spatial relationship between the N-S change of seafloor dip direction and the Rosetta Fault it is suggested that the faultparallel fold was related to the Rosetta Fault.

Across the sediment thick located in the immediate hanging wall of the Rosetta Fault, the Noor trends NE and changes to the north as it crosses the fault-parallel fold (Fig. 14A). Downslope of the fault-parallel fold, through the middle reach, the channel-levee system swings around the east-plunging nose of the NDOA, changing from a northward to a northwestward trend (Fig. 14A). The spatial relationships between the changes of channel-levee system trend, the fault-parallel fold, the NDOA, as well as the observation that the erosional fairway truncates the axis of the fault-parallel fold (Fig. 4B) all suggest that the fault-parallel fold and the NDOA were topographic features on the seafloor prior to, and/or during the evolution of the Noor.
Post-Noor Deformation.-Reflections between the top surface of Noor and the seabed are offset up to $15 \mathrm{~ms}(\sim 20 \mathrm{~m})$ by the Rosetta Fault, indicating limited post-Noor structural activity (Fig. 14B, C). The low offset suggests that structural activity related to the Rosetta Fault has not significantly changed the morphology of the preserved longitudinal profiles. The fault-parallel fold is interpreted to have been produced by movement along the Rosetta Fault, and as post-Noor movement on the fault is considered negligible, late movement of the fault-parallel fold is also considered to be minimal. No evidence of later fault-parallel fold movement can be observed on the seismic.

Above the NDOA, folding of the seabed is observed (Fig. 5), which indicates that uplift on the NDOA occurred after abandonment of the Noor channel-levee system, or that differential compaction occurred across the previously uplifted structure. Furthermore, above the NDOA, the thalweg and flanks of the Noor are convex-up, suggesting that postNoor deformation on the NDOA may have locally altered the longitudinal profile of the Noor (Figs. 5A, 6). This local deformation does not, however, influence the overall broadly concave-up thalweg longitudinal profile of the Noor.

\section{DISCUSSION}

Structural Control on Channel Location.-Changes in the trend of the Noor channel-levee system are observed to show a relationship with the location of the Rosetta Fault, the Nile Delta Offshore Anticline (NDOA), and the fault-parallel fold (Figs. 1, 8, 14A). The Noor system changes orientation by approximately $120^{\circ}$ from NE-trending in the immediate hanging wall of the Rosetta Fault to NNW-trending as the channel swings downslope around the east-plunging nose of the NDOA (Figs. 1, $8,14 \mathrm{~A})$. Seafloor topography related to local structural deformation is interpreted to have exerted a significant control on the location and trend of the Noor channel-levee system. Similar structural controls on the trend of submarine channel systems have been documented by McGilvery and Cook (2003), Morgan (2004), Gee and Gawthorpe (2006), and Clark and Cartwright (2009). Samuel et al. (2003) and Cross et al. (2009) show that several older Pliocene channel systems from the Nile Delta slope show no structural control on location and trend related to the NDOA despite their spatial proximity to the structure. Similarly, many Pleistocene channel systems show no influence on channel trend by the NDOA (Catterall 2010). These differences in channel-structure interactions are likely to be related to the relative rates of structural deformation and erosion and/or sedimentation. The Noor system reflects the situation where structural growth outpaced sedimentation, and thus channel location and trend were modified by local changes of seafloor topography driven, in this case, by tilting and fold growth.

Controls on the Downslope Change of Channel Morphology and Architecture.-The upper reach of the Noor is characterized by an erosional fairway that is $70-300 \mathrm{~m}$ deep and $10 \mathrm{~km}$ wide (Table 4). This erosional fairway is flanked by relatively thin outer levees and is filled with deposits related to collapse of the fairway margins, isolated channels with adjacent inner levees, and thick abandonment and prodelta deposits (Figs. 9, 15A). The presence of an erosional fairway and the fill of the

FIG. 13.-Morphology of outer levee 1. A) Time-thickness map of the eastern outer levee 1 of the Noor channel-levee system showing an increase of levee thickness downslope. B) Time-dip map of the top surface of outer levee 1 showing a field of sediment waves that are oriented $\sim 40^{\circ}$ to the thalweg of the Noor channel-levee system. The orientation of the sediment waves indicates that overbank sedimentation was oblique to the Noor. C) Seismic section along the eastern flank of the Noor channel-levee system. For location of seismic section, see dashed line in part A. No resolvable erosion of the top of outer levee 1 is observed and thickening upslope takes place only locally associated with fault growth. D) Undulating reflections are consistent with updip migration of sediment waves (cf. Migeon et al. 2001; Wynn and Stow 2002). 
A
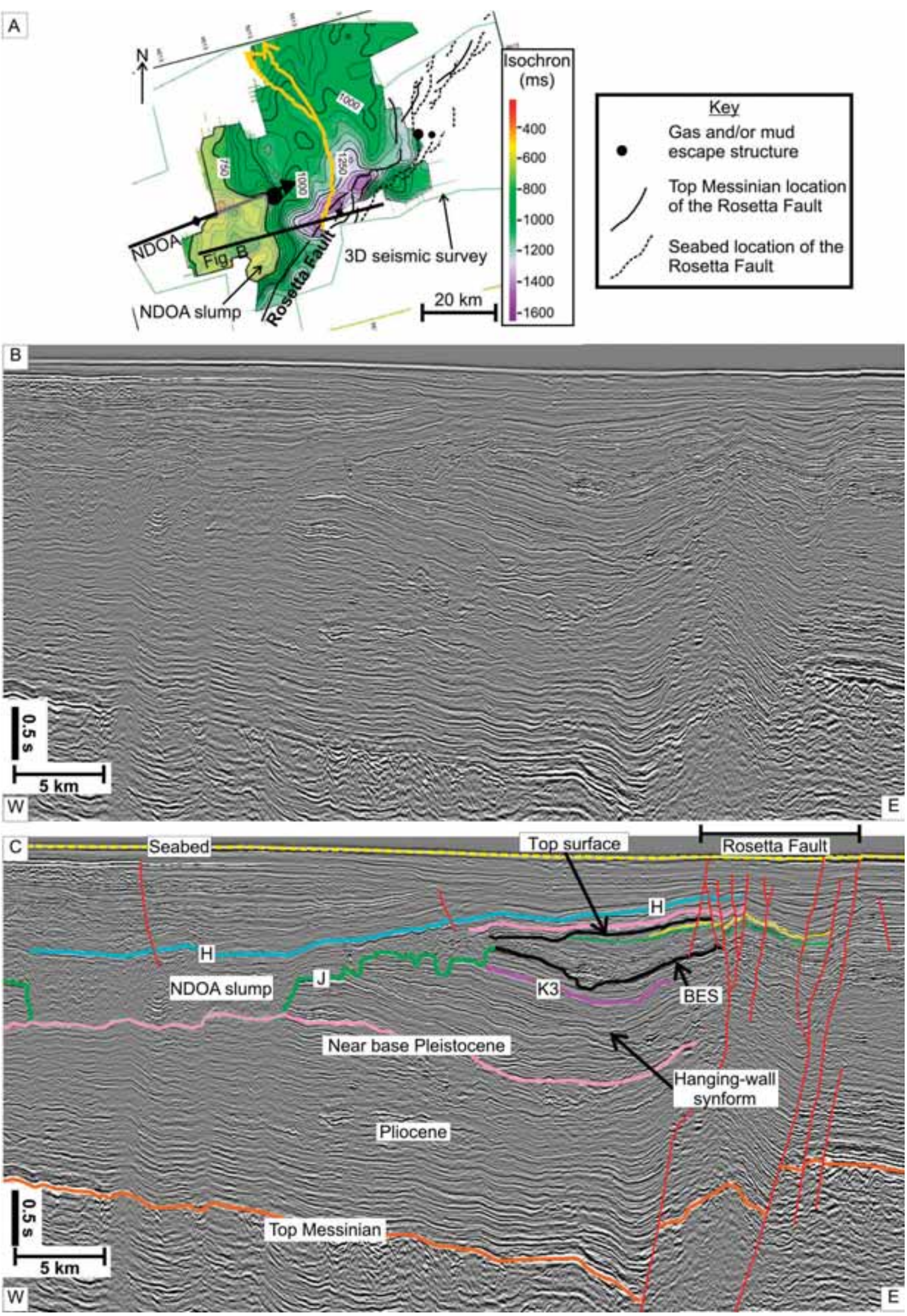
TABLE 4.- The morphometrics of several turbidite systems, including the Noor, Zaire, Amazon, and Indus. For specific settings in each system the relief, width, and aspect ratio of the erosional fairway, and the thalweg slope $(\mathrm{m} / \mathrm{km})$, are presented. In addition, the length of each system and the duration over which the system has been active is also shown. The relief and width measurements of Noor are most similar to the Amazon system but are generally smaller than all other systems. In all systems aspect ratio increases downslope (i.e., erosional-fairway size declines) as a function of relief. The thalweg slope of

Noor is steeper than the other systems, and the distance over which equivalent changes of architecture take place is greatly reduced.

\begin{tabular}{|c|c|c|c|c|c|c|c|c|}
\hline & \multicolumn{2}{|r|}{ Noor } & \multicolumn{2}{|c|}{ Modern Zaire } & \multicolumn{2}{|c|}{ Modern Indus } & \multicolumn{2}{|c|}{ Modern Amazon } \\
\hline & Upper reach & $\begin{array}{c}\text { Middle \& } \\
\text { lower reaches }\end{array}$ & Canyon & $\begin{array}{c}\text { Upper } \\
\text { channel-levee }\end{array}$ & Canyon & $\begin{array}{c}\text { Upper } \\
\text { channel-levee }\end{array}$ & Canyon & $\begin{array}{l}\text { Upper } \\
\text { fan }\end{array}$ \\
\hline Relief (m) & $70-300$ & $30-250$ & $1300(\max )$ & $150-250$ & 1000 & $300-400$ & $150-500$ & $50-200$ \\
\hline Width (km) & 10 & $2-4$ & 15 & $\begin{array}{l}1.5-2 \\
(5 \max )\end{array}$ & 10 & $10-13$ & 5-13 & $5-2$ \\
\hline Aspect ratio & $142-33$ & $\begin{array}{l}16-66 \\
\text { Average }=25 \text { for the } \\
\text { E. CLC \& } 62 \text { for the } \\
\text { W. CLC }\end{array}$ & 11 & $10-20$ & 10 & 33 & $26-33$ & $10-100$ \\
\hline Slope $(\mathbf{m} / \mathbf{k m}) \&\left({ }^{\circ}\right)$ & $\begin{array}{l}17^{*}\left(10^{\circ}\right) \\
\& 4^{\wedge}\left(0.2^{\circ}\right)\end{array}$ & $\begin{array}{l}\mathrm{KPF}=50\left(2.9^{\circ}\right) \\
\text { Middle }=15\left(0.9^{\circ}\right) \\
\text { Lower }=10\left(0.6^{\circ}\right)\end{array}$ & $\begin{array}{c}5-12 \\
\left(0.3-0.7^{\circ}\right)\end{array}$ & $\begin{array}{c}3-7 \\
\left(0.2-0.4^{\circ}\right)\end{array}$ & $13\left(0.7^{\circ}\right)$ & $\begin{array}{l}7.5-10 \\
\left(0.4-0.6^{\circ}\right)\end{array}$ & $\begin{array}{c}8-15^{1} \\
\left(5.5-0.9^{\circ}\right) \text { or } \\
25\left(1.4^{\circ}\right)^{2}\end{array}$ & $\begin{array}{l}4-8^{1} \text { Or } \\
10\left(0.6^{\circ}\right)^{2}\end{array}$ \\
\hline Length (km) & $60(\mathrm{p}$ & otential 300) & & 800 & & 500 & 700 & \\
\hline Sediment source & & Nile Delta & Zaire $\mathrm{F}$ & iver estuary & & s Delta & Amazor & iver \\
\hline Age & & Pleistocene & & gocene & middle Oligo & e to early Miocene & middle $\mathrm{N}$ & cene \\
\hline
\end{tabular}

Data are from Summerhayes et al. (1978), Coleman et al. (1981), Brice et al. (1982), Damuth and Flood (1984), Milliman et al. (1984), van Weering and van Iperen (1984), Kolla and Coumes (1987), Said (1993), Wetzel (1993), Hoorn et al. (1995), Pirmez and Flood (1995), Droz et al. (1996), von Rad and Tahir (1997), Clift et al. (2001), Babonneau et al. (2002), Walsh and Nittrouer 2009, In addition ${ }^{1}=$ Pirmez and Flood (1995), ${ }^{2}=$ Damuth and Flood $(1984),{ }^{3}=$ Lopez 2001. ${ }^{*}=\mathrm{a}$ maximum thalweg slope of $17 \mathrm{~m} / \mathrm{km}$ for the upper reach was calculated over the first $3 \mathrm{~km}$ of Noor. $\wedge=$ thalweg slope over the entire upper reach (first $15 \mathrm{~km}$ of Noor).

Noor make it similar to the proximal reaches of several other major channel-levee systems, including the "degradational" section of the ancient Indus fan, which is characterized by an erosional fairway largely filled with prodelta muds (McHargue and Webb 1986), and the canyon and canyon-mouth setting of the Pab fan, which is characterized by an erosional fairway flanked by thin outer levees (Eschard et al. 2003).

The middle and lower reaches of the Noor channel-levee system are characterized by an erosional fairway $30-250 \mathrm{~m}$ deep and 2-4 km wide, which is flanked by multistory outer levees (Table 4) (Figs. 10, 11, 15A). Channels, which show a component of lateral offset, fill the erosional fairway as well as accommodation created by aggradation of outer levees (Figs. 10, 11, 15A). Similar multistory stacked channel-levees that lead to the development of channel-levee complexes located within and above the confines of an erosional fairway characterize the "aggradational zone" of the ancient Indus fan (McHargue and Webb 1986), the "upper channel-levee" of the modern Zaire fan (Babonneau et al. 2002), and the "upper fan" setting of the modern Amazon channel (Pirmez and Flood 1995).

Comparison of the architecture of the Noor with several other channellevee systems suggests that the upper reach of the Noor is similar to a degradational canyon and the middle and lower reaches are equivalent to aggradational upper channel-levee and/or fan settings (Fig. 15B, C). The downslope changes in Noor architecture are coincident with its broadly concave-up thalweg longitudinal profile, suggesting a relationship between architecture and thalweg slope. A similar relationship has been documented from the Amazon and Rhone fans, and offshore West Africa (Pirmez et al. 2000; Ferry et al. 2005). Across upper slopes that are relatively steep compared to downslope, channel systems are dominantly erosional, whereas downslope, as thalweg gradient declines and flow size diminishes, aggradation dominates (Pirmez et al. 2000).

In the Indus, Zaire, and Amazon fans, the transition from dominantly erosional to aggradational confinement is located at the base of the upper slope defined by the first major break in slope along the length of the channel system (McHargue and Webb 1986; Babonneau et al. 2002; Pirmez and Flood 1995; Fig. 15C). In the Noor, the transition takes place across the knickpoint, created by erosion of the fault-parallel fold by the Noor, suggesting that a change of seafloor topography driven by structural deformation controlled the location of the transition zone from a canyon to channel-levee.

Although the architectural styles of the Noor, Amazon, Zaire, and Indus systems change in a similar manor downslope, in the Noor the transition from a degradational to aggradational architecture takes place over $<60 \mathrm{~km}$ whereas in the Amazon the transition takes place over $\sim 300 \mathrm{~km}$ (Pirmez and Flood 1995) (Table 4). While high sedimentation rates, associated with a tropical climate, and older age of the Amazon compared to the Noor likely played a role in the increased length of the transition zone of the Amazon, the downslope reduction of erosional fairway size (width and relief) of the Noor and Amazon systems are comparable (Table 4). Hence, the downslope reduction of erosionalfairway size is rapid in the Noor relative to the Amazon. In addition, the canyon to channel-levee transition zone of the Noor is also shorter in comparison to the Zaire systems (Babonneau et al. 2002). The different length scales of the canyon to channel-levee transition zone of these four systems are likely to have been controlled by the interplay between

FIG. 14.- Structural deformation. A) Isochron map (ms) of the interval from the near the base of the Pleistocene to key surface H. For stratigraphic orientation of these surfaces, see part C. The isochron map shows thickening into the immediate hanging wall of the Rosetta Fault, across which the upper reach of the Noor channellevee system trends NNE. Prominent thinning is marked by the $1250 \mathrm{~ms}$ contour, and this thickness change is coincident with the fault-parallel fold. B) Uninterpreted seismic strike section across the updip mapped limits of Noor (section location shown in part A). C) Interpreted seismic strike section shown in part A. A synform developed in the hanging wall of the Rosetta Fault. Across the Rosetta Fault, reflections between the top surface and seabed surfaces are offset by less than 20 ms. While these offset reflections indicate that post depositional activity on the Rosetta Fault took place, the activity is considered relatively insignificant in terms of causing major changes to the preserved longitudinal profiles. This figure is in color in the on-line version. 
A

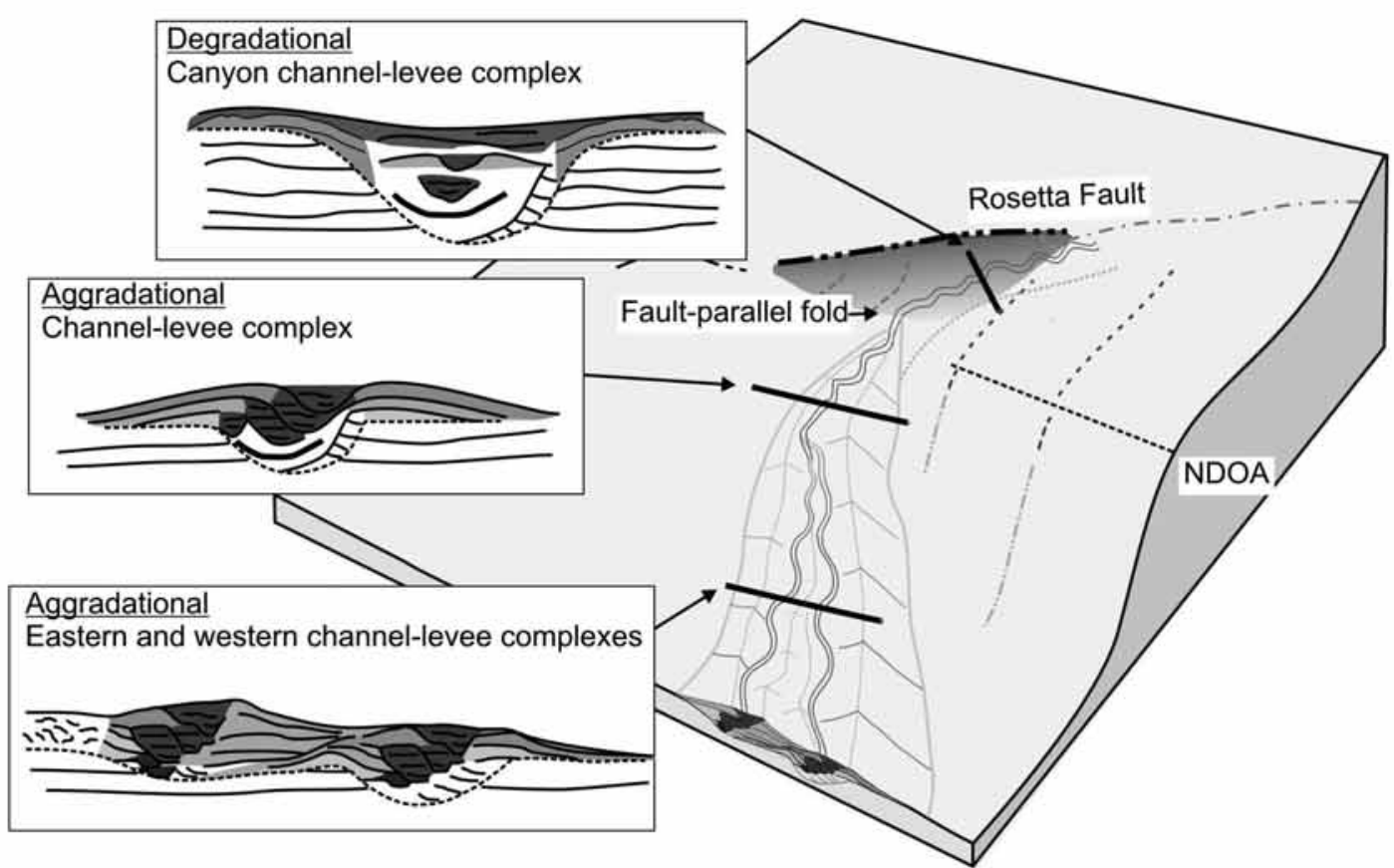

B Canyon Upperfanvalley Upperchannel-levee Lower channel-levee Lobes

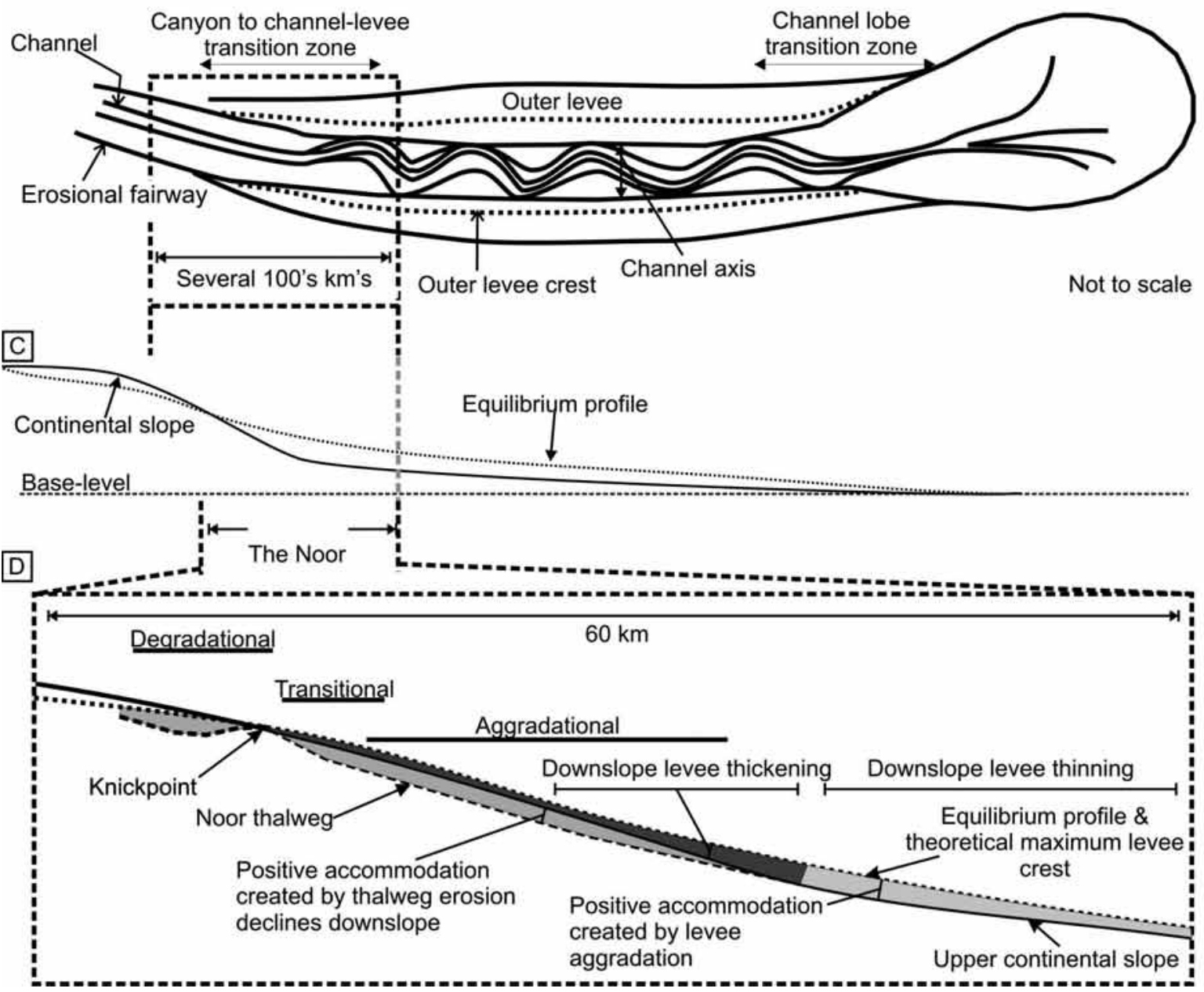


longevity of the system (controlling total sediment supply) and margin physiography. Sediment caliber is not the most likely control on the observed differences of system morphology since the four systems are largely mud-rich or characterized by a large mud-rich component. In the case of the Noor system the relatively small length scale of the canyon to channel-levee transition zone, the relatively rapid downslope decline of erosional-fairway size, and steepened thalweg slope was controlled by the relatively short and steep nature of the Nile Delta slope, which is in part controlled by the compression tectonics of the eastern Mediterranean (Robertson and Dixon 1984; Le Pichon et al. 1995; Aksu et al. 2005).

The Impact of Flow Processes on Channel Architecture.-The location of the change from a degradational to aggradational architecture shows a relationship with the fault-parallel fold. Downslope of the fold, stacking of outer levees and channels above the confines of the erosional fairway is observed, whereas upslope erosional confinement, related to the erosional fairway, dominates (Fig. 15A). Based on the relationship between the change of seafloor topography associated with the fault-parallel fold and channel-levee system architecture, flow processes were modified by seafloor topography leading to the observed downslope change of architecture. As well as changes of seafloor topography across the fold, the relief and width of the erosional fairway and Noor thalweg slope generally decreased downslope of the fold through the upper reach and middle reach (Table 4). Middleton (1966), studying straight channels, observed that as slope declines turbidity current thickness increases as a function of velocity reduction. Thus, as turbidity currents thickened downslope of the knickpoint they more likely overtopped the erosional relief of the curvilinear erosional fairway as it decreased downslope. This process may explain the onset of overbank turbidite sedimentation and levee development downslope of the fold.

Development of a hydraulic jump associated with the fold-related knickpoint may also have contributed to levee growth. Several authors have suggested that hydraulic jumps related to an abrupt shallowing of the slope lead to increased levee sedimentation adjacent to submarine channels (e.g., Menard 1964; Eschard et al. 2003). Experimental work carried out by Garcia and Parker (1989) and Garcia (1993) showed that while increased bedload deposition coincides with the hydraulic jump, the zone of enhanced deposition of the suspended load is displaced downstream and hydraulic jumps can affect the suspended sediment load over a distance 1000 times the jump height. A zone of enhanced deposition of the suspended-sediment load related to the Noor knickpoint may also have contributed to the establishment of multistory outer levees downslope of the knickpoint.

In the Noor, downslope levee thickening was observed through the middle and lower reaches (Fig. 6B). Downslope levee thickening is an unusual feature of submarine channel systems, in that it more typically has been reported that levees thin downslope (e.g., Pirmez and Flood 1995; Babonneau et al. 2002; Skene et al. 2002). Pirmez and Imran (2003) suggested that downslope levee thinning is related to a downslope reduction of sediment as it is lost to overbank sedimentation. Downslope levee thickening in the Noor system might, however, be explained by an increase of suspended sediment load due to a hydraulic jump that overcame the normal down-channel sediment loss due to overbank sedimentation as suspended-sediment volume increased.

In the Amazon, Zaire, and Indus turbidite systems, the canyon to channel-levee transition zone is also marked by a knickpoint related to the base of the upper slope, however, no downslope levee thickening is observed (McHargue and Webb 1986; Pirmez and Flood 1995; Babonneau et al. 2002). Therefore, development of a hydraulic jump related to a knickpoint is insufficient to explain downslope levee thickening. It is therefore concluded that the relatively steep slope across the northern limb of the NDOA, caused a downslope increase of overbank sedimentation, due to an increase of turbidity-current velocity and turbulence, which was sufficient to overcome the downslope loss of sediment due to overbank sedimentation.

Temporal Evolution.-Submarine channel-levee systems like the Noor that are characterized by an erosional fairway filled with multistory channels have been documented in turbidite systems other than the Zaire, Indus, and Amazon systems. These include the Pliocene offshore Nile Delta (Samuel et al. 2003; Cross et al. 2009), the Niger Delta (Deptuck et al. (2003), the Gulf of Mexico (Joshua channel, Posamentier 2003), and offshore West Africa (Mayall et al. 2006). In these studies, authors have suggested that erosional fairways initiated during times of lowered sea level and that relative sea-level rise during channel-fill stages accounts for a decrease in sediment supply through time, leading to the observed fining-upwards trend, reduced size of younger channel-levees within and above the confines of an erosional fairway, and development of inner levees after outer levees (Deptuck et al. 2003; Samuel et al. 2003; Mayall et al. 2006, Cross et al. 2009). The Noor channel-levee system shares some similarities with the aforementioned analogs, and its initiation and fill might therefore also have been influenced by changes in relative sea level. At present, this cannot be corroborated due to a lack of lithological calibration and dating control. A recent study of Pleistocene turbidite systems on the Nile Delta margin revealed that over the last $200 \mathrm{kyr}$ turbidite systems were more active during periods of rising and high sea level associated with wetter climates (and increased sediment input) rather than during lowstands (Ducassou et al. 2009). While these Pleistocene turbidite systems comprise a canyon, a channel, and a lobe (Ducassou et al. 2009), their detailed architecture is however unknown.

The Noor is characterized by at least two temporal changes of flow properties; the first initiates the erosional fairway, and the second results in the fill. Several smaller-scale changes of flow properties may have led to the cut and fill of channels located within the erosional fairway as has been suggested in other studies (e.g., Deptuck et al. 2003; Samuel et al. 2003). Multistory channels and outer levees associated with aggradation dominate the middle and lower reaches of the Noor. Previous workers have demonstrated that aggradation is the dominant process in situations of positive accommodation, when the thalweg of a channel sits below the equilibrium slope profile (Kneller 2003; Ferry et al. 2005). Throughout the fill phase of the Noor, the middle and lower reaches were largely in a state of positive accommodation, allowing aggradation to dominate (Fig. 15). The implication is that despite the Noor experiencing temporal changes of flow properties, its architectural style was largely governed by the slope profile.

FIG. 15.-Schematic illustration of the depositional setting and architectural style of the Noor system and relationship to the equilibrium slope profile. A) Schematic diagram to show the downslope change of architecture of the Noor from a degradational to an aggradational style. B) Plan-form illustration of turbidite system morphology showing some of the terminology used in this study (modified from Kane et al. 2007). The downslope change from a canyon to upper channel-levee setting in the Indus, Amazon, and Zaire systems typically takes place across hundreds of kilometers. In the Noor it takes place across $<60 \mathrm{~km}$. C) Schematic profiles of the continental shelf, slope, and equilibrium profile. D) Focus on the Noor channel-levee system to show its approximate location on the slope, thalweg longitudinal profile, and architectural style. The middle and lower reaches are in a state of positive accommodation, responsible for the observed aggradation of channels and outer levees. 


\section{CONCLUSIONS}

A 3D seismic dataset allowed description of seismic facies and channellevee architecture, as well as quantification of the morphology of the Pleistocene age Noor channel-levee system (e.g., thalweg longitudinal profile, relief, width, and levee thickness) in order to better understand channelized-flow processes and resultant stratigraphic architectures. The Noor channel-levee system is located in a structurally complex area of the Nile Delta slope. Structural growth outpaced sedimentation, and channel location and trend were modified by local changes of seafloor topography driven, in this case, by fault-related tilting and fold growth.

Noor architecture changed downslope from a degradational canyonlike proximal reach to an aggradational middle reach, characterized by multistory channel-levees. This downslope distribution of architecture is similar to that found in the Zaire, Amazon, and Indus turbidite systems. Although many factors control the morphology of channel-levee systems, including the rate, type, and source of sediment supply, and sea-level fluctuations, this study demonstrates the strong link between architecture and the slope profile, supporting previous work from other depositional systems. The transition from a degradational to an aggradational architecture is associated with a break in slope in all four examples. What makes the Noor an important case study is the structural control on seafloor topography that is associated with the location of the transition and its short length scale.

The downslope decline of erosional-fairway size of the Noor and Amazon systems are similar, however, the length scale of this decline is significantly reduced in the Noor and its thalweg slope is steeper than that observed in other systems. Another feature is that in the Noor, levees are observed to thicken downslope. This is interpreted to be caused by a downslope increase of overbank sedimentation potentially related to the presence of a knickpoint but more likely due to the steepened slope profile, which produced an increase of turbidity-current velocity, thickness, and turbulence. This was sufficient to overcome the normal downslope loss of sediment due to progressive overbank sedimentation.

This study demonstrates the utility of quantifying channel-levee morphology in parallel with qualitative description of architecture to unravel the morphological control and development of submarine channels. This case study highlights the control of structural deformation on seafloor topography, and its impact on channel-levee morphology and architecture, which contributes towards the development of predictive models for the evolution of submarine channel-levee systems in other depositional systems.

\section{ACKNOWLEDGMENTS}

We thank BG Group and EGAS for making the data available to the University of Manchester and Matt Wakefield, John Cole, Rick Moore, Hamish McIntyre, and Tim Pointer at BG Group. Ph.D. sponsorship for VC was from a National Environmental Research Council (NERC) industrial CASE award (NER/S/A/2005/13216). Lorna Strachan, Simon Brocklehurst, Ivan Fabuel-Perez, and Duncan Irving are thanked for technical input and support. Schlumberger is acknowledged for providing seismic interpretation software. We gratefully acknowledge careful and constructive reviews from associate editors Carlos Pirmez, Steve Hubbard, and anonymous reviewers.

\section{REFERENCES}

Abdel Aal, A., El Barkooky, A., Gerrits, M., Meyer, H., Schwander, M., and Zaki, H., 2000, Tectonic evolution of the Eastern Mediterranean basin and its significance for hydrocarbon prospectivity of the ultradeepwater of the Nile Delta: The Leading Edge, v. 19, p. 1086-1102

Abdel Aal, A., El Barkooky, A., Gerrits, M., Meyer, H., Schwander, M., and Zaki, H. 2001, Tectonic evolution of the Eastern Mediterranean basin and its significance for hydrocarbon prospectivity in the Nile Delta deepwater area: GeoArabia, v. 6, p. 363-384.

Al-Chalabi, M., 1997a, Parameter nonuniqueness in velocity versus depth functions: Geophysics, v. 62, p. $970-979$
At-Chalabi, M., 1997b, Time-depth relationships for multilayer depth conversion: Geophysical prospecting, v. 45, p. 715-720.

Aksu, A.E., Hall, J., and Yaltirak, C., 2005, Miocene to recent tectonic evolution of the eastern Mediterranean: new pieces of an old Mediterranean puzzle: Marine Geology, v. 21, p. 1-13

Babonneau, N., Savoye, B., Cremer, M., and Klein, B., 2002, Morphology and architecture of the present canyon and channel system of the Zaire deep-sea fan: Marine and Petroleum Geology, v. 19, p. 445-467.

Beaubouef, R.T., 2004, Deep-water leveed-channel complexes of the Cero Toro Formation, Upper Cretaceous, southern Chile: American Association of Petroleum Geologists, Bulletin, v. 88, p. 1471-1500.

Bouma, A.H., Colmman, J.M. DSDP Leg 96 Shipboard Scientists, 1985, Mississippi fan: leg 96 program and principal results, in Bouma, A.H., Normark, W.R., and Barnes, N.E., eds., Submarine Fans and Related Turbidite Systems: New York, Springer-Verlag, p. 247-252.

Brice, S.E., Cochran, M.D., Pardo, G., and Edwards, A.D., 1982, Tectonics and sedimentation of the South Atlantic rift sequence: Cabinda, Angola, in Drake, W. A. ed., Studies in Continental Margin Geology, American Association of Petroleum Geologists, Memoir 34, p. 5-18

CAtTerall, V., 2010, Evolution and quantification of submarine slope systems: offshore Nile Delta [Ph.D. Thesis]: University of Manchester, U.K., 327 p.

Clark, I., and CARTwright, J., 2009, Interactions between submarine channel systems and deformation in deepwater fold belts: Marine and Petroleum Geology, v. 26, p. $1465-1482$.

Clift, P.D., Shimizu, N., Layne, G.D., Blusztajn, J.S., Gaedicke, C., Schlüter, H.-U., Clark, M.K., and Amjad, S., 2001, Development of the Indus Fan and its significance for the erosional history of the Western Himalaya and Karakoram: Geological Society of America, Bulletin, v. 113, p. 1039-1051.

Clark, M.K., and Amjad, S., 2001, Development of the Indus Fan and its significance for the erosional history of the Western Himalaya and Karakoram: Geological Society of America, Bulletin, v. 113, p. 1039-1051.

Coleman, J.M., Roberts, H.H., Murray, S.P., and Salama, M., 1981, Morphology and dynamic sedimentology of the eastern Nile Delta shelf: Marine Geology, v. 42, p. 301-326.

Cross, N.E., Cunningham, A., Cook, R.J., Taha, A., Esmaie, E., and El Swidan, N., 2009. Three-dimensional seismic geomorphology of a deep-water slope-channel system: the Sequoia field, offshore west Nile Delta, Egypt: American Association of Petroleum Geologists, Bulletin, v. 93, p. 1063-1086.

Damuth, J.E., And Flood, R.D., 1984, Morphology, sedimentation processes, and growth pattern of the Amazon deep-sea fan: Geo-Marine Letters, v. 3, p. 109-117.

Damuth, J.E., Kowsmann, R.O., Flood, R.D., Belderson, R.H., and Gorini, M.A., 1983, Age relationships of distributary channels on Amazon deep-sea fan: implications for fan growth pattern: Geology, v. 11, p. 470-473.

Deptuck, M.E., Steffans, G.S., Barton, M., and Pirmez, C., 2003, Architecture and evolution of upper fan channel-belts on the Niger Delta slope and in the Arabian Sea: Marine and Petroleum Geology, v. 20, p. 649-676,

Deptuck, M.E., Sylvester, Z., Pirmez, C., and O'Byrne, C., 2007, Migrationaggradation history and 3-D seismic geomorphology of submarine channels in the Pleistocene Benin-major Canyon, western Niger Delta slope: Marine and Petroleum Geology, v. 24, p. 406-433.

Droz, L., Rigaut, F., Cochonat, P., and Tofani, R., 1996, Morphology and recent evolution of the Zaire turbidite system (Gulf of Guinea): Geological Society of America, Bulletin, v. 108 , p. 253-269.

Ducassou, E., Migeon, S., Mulder, T., Murat, A., Capotondis, L., Bernasconi, S.M., and Mascle, J., 2009, Evolution of the Nile deep-sea turbidite system during the Late Quaternary: influence of climate change on fan sedimentation: Sedimentology, v. 56, p. 2061-2090.

Eschard, R., Albouy, E., Deschamps, R., Euzen, T., and Ayub, A., 2003, Downstream evolution of turbiditic channel complexes in the Pab range outcrops (Maastrichtian, Pakistan): Marine and Petroleum Geology, v. 20, p. 691-710.

Ferry, J.-N., Mulder, T., Parize, O., and Raillard, S., 2005, Concept of equilibrium profile in deep-water turbidite systems: effects of local physiographic changes on the nature of sedimentary process and the geometries of deposits, in Hodgson, D.M., and Flint, S.S., eds., Submarine Slope Systems: Processes and Products, Geological Society of London, Special Publication 244, p. 181-193.

GARCIA, M., 1993, Hydraulic jumps in sediment-driven bottom currents: Journal of Hydraulic Engineering, v. 119, p. 1094-1117.

Garcia, M., and Parker, G., 1989, Experiments on hydraulic jumps in turbidity currents near a canyon-fan transition: Science, v. 245 , p. 393-396.

GARDNER, M.H., AND Borer, J.M., 2000, Submarine channel architecture along a slope to basin profile, Brushy Canyon Formation, West Texas, in Bouma, A.H., and Stone, C.G., eds., Fine-Grained Turbidite Systems, American Association of Petroleum Geologists, Memoir 72, and SEPM, Special Publication 68, p. 195-214.

Gee, M.J.R., and Gawthorpe, R.L., 2006, Submarine channels controlled by salt tectonics: examples from 3D seismic data offshore Angola: Marine and Petroleum Geology, v. 23, p. 443-458

Gee, M.J.R., Gawthorpe, R.L., Bakke, K., and Friedmann, S.J., 2007, Seismic geomorphology and evolution of submarine channels from the Angolan continental margin: Journal of Sedimentary Research, v. 77, p. 433-446.

Hoorn, C., Guerrero, J., Sarmiento, A.S., and Lorente, M.A., 1995, Andean tectonics as a cause for changing drainage pattern in Miocene northern South America: Geology, v. 23, p. 237-240. 
Kane, I.A., Kneller, B.C., Dykstra, M., Kassem, A., and McCaffrey, W.D., 2007, Anatomy of a submarine channel-levee: an example from Upper Cretaceous slope sediments, Rosario Formation, Baja California, Mexico: Marine and Petroleum Geology, v. 24, p. 540-563.

Keevil, G.M., Peakall, J., And Best, J.L., 2007, The influence of scale, slope and channel geometry on the flow dynamics of submarine channels: Marine and Petroleum Geology, v. 24, p. 487-503.

Kneller, B., 2003, The influence of flow parameters on turbidite slope channel architecture: Marine and Petroleum Geology, v. 20, p. 901-910.

Kolla, V., AND Coumes, F., 1987, Morphology, internal structure, seismic stratigraphy, and sedimentation of Indus Fan: American Association of Petroleum Geologists, Bulletin, v. 71, p. 650-677.

Le Pichon, X., Chamot-Rooke, N., Lallemant, S., Noomen, R., and Veis, G., 1995, Geodetic determination of the kinematics of central Greece with respect to Europe: implications for eastern Mediterranean tectonics: Journal of Geophysical Research, v. 100 , p. $12,675-12,690$.

Lopez, M., 2001, Architecture and depositional pattern of the Quaternary deep-sea fan of the Amazon: Marine and Petroleum Geology, v. 18, p. 479-486.

Manley, P.L., Pirmez, C., Busch, W., and Cramp, A., 1997, Grain-size characterization of Amazon Fan deposits and comparison to seismic facies units, in Flood, R.D. Piper, D.J.W., Klaus, A., and Peterson, L.C., eds., Proceedings of the Ocean Drilling Program, Scientific Results, v. 155 , p. $35-52$

Mascle, J., Zitter, T., Bellaiche, G., Droz, L., Gaullier, V., Loncke, L., Prismed SCIENTIFIC Party, 2001, The Nile deep sea fan: preliminary results from a swath bathymetry survey: Marine and Petroleum Geology, v. 18, p. 471-477.

Mayall, M., Jones, E., and CASEy, M., 2006, Turbidite channel reservoirs-key elements in facies prediction and effective development: Marine and Petroleum Geology, v. 23, p. 821-841.

McGilvery, T.A., AND COOK, D.L., 2003, The influence of local gradients on accommodation space and linked depositional elements across a stepped slope profile, offshore Brunei, in Roberts, H.H., Rosen, N.C., Fillon, R.H., and Anderson, profile, offshore Brunei, in Roberts, H.H., Rosen, N.C., Fillon, R.H., and Anderson,
J.B., eds., Shelf Margin Deltas and Linked Downslope Petroleum Systems: Global Significance and Future Exploration Potential, SEPM, Gulf Coast Section, 23r Annual Research Conference, p. 387-419.

McHargue, T.R., 1991, Seismic facies, processes, and evolution of Miocene inner fan channels, Indus Submarine Fan, in Weimer, P., and Link, M., eds., Seismic Facies, and Sedimentary Processes of Submarine Sands and Turbidite Systems: New York, Springer-Verlag, p. 402-413

McHargue, T.R., and WebB, J.E., 1986, Internal geometry, seismic facies, and petroleum potential of canyons and inner fan channels of the Indus submarine fan American Association of Petroleum Geologists, Bulletin, v. 70, p. 161-180.

Menard, H.W., 1964. Marine Geology of the Pacific: New York, McGraw Inc, $271 \mathrm{p}$ MidDleton, G.V., 1966, Experiments on density and turbidity currents (Part 2), uniform flow of density currents: Canadian Journal of Earth Sciences, v. 3, p. 627-637.

Migeon, S., Savoye, B., Zanella, E., Mulder, T., Faugeres, J.-C., and Weber, O., 2001, Detailed seismic-reflection and sedimentary study of turbidite sediment waves on the Var Sedimentary Ridge (SE France): significance for sediment transport and deposition and for the mechanisms of sediment-wave construction: Marine and Petroleum Geology, v. 18, p. 179-208

Milliman, J.D., Quraishee, G.S., And Beg, M.A.A., 1984, Sediment discharge from the Indus river to the ocean: Past, present and future, in Haq, B.U., and Milliman, J.D. eds., Marine Ecology and Oceanography of the Arabian Sea and Coastal Pakistan: New York, Van Nostrand Reinhold, p. 65-70.

Morgan, R., 2004, Structural controls on the positioning of submarine channels on the lower slopes of the Niger Delta, in Davies, R.J., Cartwright, J.A., Stewart, S.A Lappin, M., and Underhill, J.R., eds., 3D Seismic Technology: Application to the Exploration of Sedimentary Basins, Geological Society of London, Memoir 29, p. $45-51$.

Normark, W.R., Posamentier, H., and Mutti, E., 1993, Turbidite systems: state of the art and future direction: Reviews of Geophysics, v. 31, p. 91-116.

Piper, D.J.W., Hiscott, R.N., AND Normark, W.R., 1999, Outcrop-scale acoustic facie analysis and latest Quaternary development of Hueneme and Dume submarine fans, offshore California: Sedimentology, v. 46, p. 47-78.
Pirmez, C., And Flood, R.D., 1995, Morphology and structure of Amazon channel, in Flood, R.D., Piper, D.J.W., Klaus, A., and Peterson, L.C., eds., Proceedings of the Ocean Drilling Program, Initial Report, v. 155, p. 23-45.

Pirmez, C., And Imran, J., 2003, Reconstruction of turbidity currents in Amazon Channel: Marine and Petroleum Geology, v. 20, p. 823-849.

Pirmez, C., Befauboufe, R. T., Freidmann, S.J., and Mohrig, D. C., 2000, Equilibrium profile and baselevel in submarine channels: examples from late Pleistocene system and implications for the architecture of deepwater reservoirs, in Weimer, P., Slatt, R.M., Coleman, J., Rossen, N.C., Nelson, H., Bouma, A.H., Styzen, M.J., and Lawrence, D.T., eds., Deep-Water Reservoirs of the World, SEPM, Gulf Coast Section, 20th Annual Research Conference. p. 782-805.

Posamentier, H.W., 2003, Depositional elements associated with a basin floor channellevee system: case study from the Gulf of Mexico: Marine and Petroleum Geology, v. 20 , p. $677-690$

Posamentier, H.W., and Kolla, V., 2003, Seismic geomorphology and stratigraphy of depositional elements in deep-water settings: Journal of Sedimentary Research, v. 73 , p. $367-388$.

Robertson, A.H.F., And Dixon, J.E., 1984, Introduction: aspects of the geological evolution of the Eastern Mediterranean, in Dixon, E., and Robertson, A.H.F., eds. The Geological Evolution of the Eastern Mediterranean, Geological Society of London, Special Publication 17, p. 1-74.

SAID, R., 1981. The Geological Evolution of the River Nile: New York, Springer-Verlag, $151 \mathrm{p}$

SAID, R., 1993. The River Nile: Geology, Hydrology, and Utilization: Oxford, England, Pergamon Press, $320 \mathrm{p}$

Samuel, A., Kneller, B., Raslan, S., Sharp, A., and Parsons, C., 2003, Prolific deepmarine slope channels of the Nile Delta, Egypt: American Association of Petroleum Geologists, Bulletin, v. 87 , p. $541-560$.

Sheriff, R., and Geldart, L.P., 1995. Exploration Seismology: Cambridge, UK, Cambridge University Press, $592 \mathrm{p}$

Skene, K.I., PiPer, D.J.W., AND Hill, P.S., 2002, Quantitative analysis of variations in depositional sequence thickness from submarine levees: Sedimentology, v. 49, p. $1411-1430$.

SLOTNICK, M.M., 1936, On seismic computations with applications I: Geophysics, v. 1 , p. $9-22$

Summerhayes, C.P., Sestini, G., Misdorp, G., and Marks, N., 1978, Nile Delta: nature and evolution of continental shelf sediments: Marine Geology, v. 27, p. 43-65.

VAIL, P.R., 1987, Seismic stratigraphy interpretation utilizing sequence stratigraphy Part I-seismic stratigraphy interpretation procedure, in W.W. Bally, ed., Atlas of Seismic Stratigraphy, American Association of Petroleum Geologists, Studies in Geology 27, p. $1-10$.

Van Weering, T.C.E., and Van Iperen, J., 1984, Fine-grained sediments of the Zaire deep-sea fan, southern Atlantic Ocean, in Stow, D.A.V., and Piper, D.J.W., eds., FineGrained Sediments: Deep-Water Processes and Facies, Geological Society of London, Special Publication 15, p. 95-113

VoN RAD, U., AND TAHIR, M., 1997, Late Quaternary sedimentation on the outer Indus shelf and slope (Pakistan): evidence from high-resolution seismic data and coring: Marine Geology, v. 138, p. 193-236.

WAlSh, J.P., AND NitTrouER, C.A., 2009, Understanding fine-grained river-sediment dispersal on continental margins: Marine Geology, v. 263, p. $34-45$

Wetzel, A., 1993, The transfer of river load to deep-sea fans: a quantitative approach: American Association of Petroleum Geologists, Bulletin, v. 77, p. 1679-1692.

Wood, L.J., And Mize-Spansky, K.L., 2009, Quantitative seismic geomorphology of a Quaternary leveed-channel system, offshore eastern Trinidad and Tobago, northeastern South America: American Association of Petroleum Geologists, Bulletin, v. 93 p. 101-125.

WynN, R.B., AND STOw, D.A.V., 2002, Classification and characterization of deep-water sediment waves: Marine Geology, v. 192, p. 7-22.

Received 3 July 2008; accepted 24 May 2010. 